\title{
DELACIÓN FORZOSA, PRETERICIÓN Y LEGÍTIMA ASISTENCIAL: ANÁLISIS EN LOS ORDENAMIENTOS CUBANO Y ESPAÑOL (I)
}

\author{
MSC. Yanet ALFARO GUILLÉN \\ Jueza titular de la Sala SEgunda de lo Civil y lo Administrativo \\ DEL TRIBUNAL PROVINCIAL DE LA HABANA \\ PROFESORA ASISTENTE DE LA FACULTAD DE DERECHO \\ UNIVERSIDAD DE LA HABANA (CUBA)
}

SUMARIO: I. La sucesión legitimaria y los sistemas legitimarios. I.I. Definiciones. I.2. Clasificaciones de los sistemas legitimarios. I.2.I. Según su naturaleza o aspecto funcional. I.2.2. Según su contenido. I.3. Necesarias distinciones. I.3.I. Notas iniciales. I.3.2. Presupuestos distintivos de la «sucesión legitimaria». I.3.2.I. Delación. I.3.2.2. Contenido. I.3.2.3. Sujetos. I.3.2.4. Efectos. I.3.2.5. Fundamento. I.3.3. Precisiones finales. II. El sistema legitimario cubano. II.I. Función asistencial de la sucesión legitimaria en Cuba. II.I.I. Determinación del momento de valoración de los requisitos para la especial protección. II.I.2. Renunciabilidad a la condición de heredero especialmente protegido. II.r.3. Aplicación de las incapacidades relativas o indignidades sucesorias a los herederos especialmente protegidos. II.2. Características. II.3. Desaciertos fundamentales. II.3.I. En cuanto a la concepción general del régimen legitimario. II.3.2. En cuanto al régimen de protección en particular. III. Bibliografía. IV. Fuentes legales. V. Resoluciones de la Dirección General de los Registros y el Notariado. VI. Sentencias de la Sala de lo Civil y lo Administrativo del Tribunal Supremo Popular (Cuba). VII. Sentencias de la Sala de lo Civil del Tribunal Supremo (España).

RESUMEN: La autonomía de la sucesión forzosa es presupuesto indispensable para el adecuado despliegue de la protección legitimaria. Predomina en los estudios anteriores, la negación de este carácter pero los enfoques se centran en su regulación normativa y no profundizan en los postulados teóricos de la categoría. En la actualidad la demanda del carácter asistencial de la obligación legitimaria va ganando cada vez más fuerza y las reformas legislativas de las últimas décadas se van haciendo eco. En ese contexto, la debida ubicación de esta clase de sucesión mortis causa es primordial para una consecuente regulación de su régimen jurídico.

PALABRAS CLAVE: sucesión forzosa; delación forzosa; legítima asistencial; herederos legales, error del testador.

FORCED SHARE, OMISSION OF LEGAL HEIRS («PRETERITION») AND LEGÍTIMA SUCCESSION WITH MAINTENANCE FUNCTIONS: ANALYSIS OF THE SPANISH AND CUBAN LEGISLATION (I)

ABSTRACT: The conception of the forced succession as an autonomous legal calling to heirship is an indispensable ground for the proper display of the legitima system protection. The denial of this approach predominates in prior studies about this topic, where the analysis are centered in the legislation and do not deepen on theoretical postulates. Nowadays, the demand of the assistance, welfare or maintenance function in the obligation of legitima succession is gaining more and more force and the legislative reforms during the last decades are making echo of this situation. In this context, it is essential to establish the due position of this mortis causa succession for a consequent regulation of its legal regime.

KEYWORDS: compulsory succession; forced share; legal heirs; legítima; family provisions; testator's mistake. 


\section{La sucesión legitimaria y los sistemas legitimarios}

\section{I.I. Definiciones}

Los tipos de sucesión son las maneras por las cuales llega a ofrecerse la herencia o a concretarse la delación ${ }^{\mathrm{I}}$ y tradicionalmente dentro del sistema sucesorio romano se ha concebido que ello se verifique a través del testamento o la ley, identificando de este modo a las sucesiones exclusivamente como testadas o intestadas. En cambio en el modelo sucesorio germánico, se plantea sin oposiciones que son tres los tipos o formas de sucesión: testada, intestada y forzosa ${ }^{2}$. Dado que los tipos de sucesión son los que ordenan la forma en la que ha de deferirse la herencia y ese ofrecimiento se verifica con la delación, entonces para entender que también en el sistema legitimario romano existe la forzosa o legitimaria como una tercera forma sin que riña ello con su naturaleza de reglamentación negativa, es preciso sentar ciertas pautas 3 .

Hablar de «sucesión legitimaria» no resulta nada simple. Se advierte en la doctrina una infeliz equiparación de esta categoría a la de «sistema legitimario» dando al traste con importantísimos análisis que han profundizado en los puntos neurálgicos de la sucesión forzosa. Los sistemas legitimarios, pueden ser instrumentalmente definidos como el conjunto de normas, instituciones y principios que ordenan la forma en la que opera la sucesión legitimaria. Con la confusión de estas instituciones se han perdido los contornos de un relevante presupuesto de la construcción teórica de las formas de sucesión, en lo que a la autonomía y peculiaridades de la legitimaria o forzosa se refiere.

\section{I.2. Clasificaciones de los sistemas legitimarios ${ }^{4}$}

\section{I.2.I. Según su naturaleza o aspecto funcional}

En primer orden aparece la escisión de los sistemas legitimarios a partir de la clásica concepción de su naturaleza o de la más reciente terminología que alude a su aspecto funcional, pero constituyen valoraciones del mismo fenómeno. Así aparece: un

${ }^{\text {I }}$ Mientras que las formas de suceder son las vías a través de las cuales puede un individuo llegar a convertirse en sucesor de otro por causa de muerte, de modo que se refieren a las vías de acceso a la delación -a través del derecho propio, derecho de representación o derecho de transmisión-, los tipos de sucesión contienen los mecanismos de colocación o activación del ofrecimiento para que por las vías correspondientes pueda accederse.

${ }^{2}$ Este contraste de sistemas legitimarios es consecuencia de las opuestas concepciones que del fenómeno sucesorio han gestado los modelos romano y germano de adquisición de la herencia.

${ }^{3}$ Vid. infra epígrafe I.3

${ }^{4}$ El estudio de la clasificación de los sistemas legitimarios va a circunscribirse al sistema continental por ser aquel que engendra verdaderos regímenes de sucesión forzosa. El Common Law no concibe este tipo de sucesión porque rige como principio general la libertad de testar, aunque matizada por los ordenamientos contemporáneos de este tipo con las previsiones de cierta tutela familia mortis causa. En el ordenamiento inglés se prevé la family provision, limitando la libertad de testar sólo para proteger a ciertas personas dependientes económicamente del causante mediante asignaciones de cantidades monetarias suficientes. Vid. Barrio Gallardo (201I, 299-300), Cámara Lapuente (2003, I219) y Vaquer Aloy (2010, I99). Similar orientación sigue Estados Unidos cuando en su Código Uniforme de Sucesiones se protege a los hijos de la inexistencia de atribución mortis causa. Dieciocho estados han adoptado este Código. Luisiana constituye una excepción al régimen imperante en este país porque establece, aunque limitado, un régimen de legítima que no se encuentra con exactitud en ninguno de los modelos continentales. Vid. García Moreno (2008, 62I-623) y Miquel González (2009, 520-524). En las codificaciones aún vigentes en países de Europa del Este como Estonia, Lituania y Polonia, el sistema legitimario tiene un marcado carácter asistencial, cuyo régimen Vaquer, (2010, 200-20I) ha calificado como una propuesta intermedia entre los sistemas de determinación de una cuantía fija de la legítima y el sistema inglés de las provisiones familiares. 
sistema germánico, de atribución legal o de reserva legal en el que constituye la legítima una pars reservata y un sistema romano de reglamentación negativa o de freno en el que constituye una pars debita.

Sistema germánico, de atribución legal o de reserva legal: opera la legítima como una porción forzosa de la sucesión intestada de modo que la ley concede al legitimario una protección directa a través de una delación legal al margen de las disposiciones volitivas del causante mediante una reserva legal. En su contexto se habla más de una reserve que de una porción legítima.

Sistema romano de reglamentación negativa o de freno: opera la legítima como un límite a la libertad de disponer por testamento o cualquier modalidad de liberalidad inter vivos de modo que constituyen una porción de la que el causante no puede disponer libremente sino a favor de sus legitimarios. Engendra por excelencia la porción legítima.

Ha señalado Rivas Martínez (2009, I4IO y I4II) que en el denominado genéricamente sistema romano las legítimas constituyen sólo una limitación a la libertad dispositiva del causante mientras que en el denominado genéricamente sistema germánico de atribución legal, aparecen como una excepción a la posibilidad de que el causante disponga de una parte reducida de su haber y concluye que en el Código Civil español no hay una legítima de tipo rigurosamente unitario, sino diversas modalidades legitimarias dirigidas a alcanzar una finalidad práctica.

La doctrina española, contiene diversos análisis en cuanto a la calificación del sistema legitimario regulado en el ordenamiento español según este primer criterio. Se ha planteado que en la regulación del Código Civil convergen elementos de ambos sistemas ${ }^{5}$, que se trata de un sistema romano o de reglamentación negativa ${ }^{6}$ y también que se regula un sistema germánico o de reserva ${ }^{7}$. Según otro criterio ha de atenderse a la legislación concreta reguladora de la legítima para poder ofrecer la precisa calificación del sistema ${ }^{8}$.

${ }^{5}$ Real Pérez (I988, 22 y 23), afirma que la legítima española se formó tomando en cuenta elementos de ambos sistemas pero predominan las notas características del sistema romano. O'Callaghan (2006-2007, 225) plantea que en el Código Civil español se mezclan elementos de la legítima romana y la germana, esta última en lo que a la mejora se refiere aunque en Cataluña, Navarra y Baleares, se ha mantenido casi íntegramente el sistema y los principios de la legítima romana.

${ }^{6}$ Vallet $($ I972, 38) aclara que esta calificación no es absoluta, sino efectuada al contrastar el sistema legitimario español con el germánico de delación legal, indicativa de que no se regula en España una delación directa a favor de los legitimarios. El mismo autor $(1978,8)$ advierte que no es pars reservata por razón de la interpretación histórica y sistemática del artículo 806 frente a las cuales la literal no tiene suficiente fuerza y que las expresión de que no puede disponer empleada en el precepto no implica que el causante no pueda disponer de la parte de su patrimonio relicto -en la técnica de la reserva germánica- sino que admite que el causante pueda disponer de todos sus bienes pero en atención a las limitaciones que se establecen en el propio código en materia de legítima. Que tampoco la expresión por haberla reservado la ley tiene la trascendencia del sostenimiento de la tesis germana sino que es empleado sólo en su acepción gramatical. Rivas (2009, I4I0 y I4II) ha entendido que el sistema de reglamentación negativa o de freno es el seguido fundamentalmente por el Código Civil español porque la ley deja hacer y disponer al causante en cuanto éste cumpla voluntariamente el deber que le impone y no se salga de los límites que le señala para disponer con uno u otro destino, y sólo confiere al legitimario, en forma subsidiaria, derecho de impugnación, o bien al complemento, cuando en perjuicio suyo el testador o donante se hubiese excedido de las limitaciones señaladas en la ley.

7 Vid. vgr. Ortega Pardo (I959, 361) y Peña Bernaldo de Quirós (I985, 850 y ss.).

8 Roca Sastre y Puig Brutau (2009, I80) distinguen dentro del Derecho español tres grupos de legislaciones en cuanto al sistema de legítimas:

I. En los territorios de Derecho Común, sistema romano, con influjo de la reserva germana, quantum más reducido y la flexibilidad de las mejoras.

2.Cataluña y Baleares fuertemente romanizadas, sistema romano del período clásico Cataluña, Mallorca sistema justinianeo o de legítima elevada y variable.

3. Aragón, Navarra y Vizcaya, regiones del Fuero de Ayala y del Privilegio de Ager, no recibieron en toda su pureza el sistema legitimario romano clásico ni tampoco el fuertemente limitativo de la reserva germánica. 
De la Cámara Álvarez (20II, I92 y I93) en enfoque similar advierte tres sistemas que pretenden determinar la naturaleza de la legítima y concluye la pertenencia del ordenamiento español al tercero de ellos:

I. La legítima como parte de la herencia que se defiere ab intestato a los legitimarios de modo que el testador solo podrá disponer mortis causa o a título gratuito de una parte de la herencia. Según la doctrina dominante en Italia, una variante de este sistema es la de imaginar junto a la delación ab intestato y testamentaria que existe un tercer tipo de delación o llamamiento ex lege a una cuota del haber hereditario. La legítima aquí es pars hereditatis y tiene su máxima expresión en el derecho francés.

2. Sistema opuesto al primero, el legitimario por el hecho de serlo sólo ostenta un crédito contra la herencia por el valor que represente su legítima. Aquí el legitimario no es heredero por lo que la legítima será pars valoris o pars valoris bonorum. Es el sistema que adopta el ordenamiento alemán.

3. La legítima se concibe como obligación o deber impuesto al testador de dejar una parte de su patrimonio líquido a los legitimarios, pero se permite al testador que elija la forma en que pueda cumplir esa obligación? 9 .

Considero que el sistema legitimario del Código Civil español corresponde al modelo de reglamentación negativa. Dada la imprecisa redacción del artículo 806 del Código, las acciones de protección a la intangibilidad cuantitativa de la legítima, reguladas en lo fundamental ${ }^{10}$ en los artículos 8I4 y 8I5, delatan este carácter si se tiene en cuenta que su objeto es privar de efectos a las disposiciones volitivas del testador que lesionen derechos legitimarios. Ello conduce indubitadamente, a la conclusión de que opera la sucesión legitimaria como límite a la libertad de testar y no como atribución legal directa.

\section{I.2.2. Según su contenido}

En segundo orden se califican los sistemas legitimarios atendiendo a su contenido fundamentalmente en sistemas pars hereditatis, pars valoris, pars valoris bonorum $y$ pars bonorum ${ }^{\text {II }}$.

Pars hereditatis: opera atribuyendo al legitimario la condición de heredero para que reciba una parte de la herencia integrada tanto por activo como por pasivo.

En estas regiones es posible, gracias a la legítima ficticia o reducida, acumular los bienes en un sólo heredero posibilitándose con ello la subsistencia indefinida del tipo de familia troncal.

9 En este último se discute con mucha fuerza la interrelación de la observancia del principio de libertad de testar y la limitación que las legítimas imponen a esta sui generis libertad individual. Los análisis discurren por los senderos del cuestionamiento de la preservación, actualización o flexibilización del deber legitimario a partir de las vigentes condiciones socioeconómicas que tanto difieren de las que motivaron su surgimiento. Cfr. Rivas Martínez (2009, I406-I407), O'Callaghan (2008, 800); Valladares Rascón (2004, 4893), Barrio Gallardo (2007, 27I4), Rentería Arocena (20II, 2I06), Delgado Echeverría (20II, 8), Miquel González (2009, 497 y 499-500), Torres García, (2006, 220), Vaquer Aloy (2010, I94-I96) y Cámara Lapuente (2003, I218, I224 y I225). Realmente se advierte este debate sólo en el plano de las disquisiciones teóricas, porque en el legislativo aunque se matizan y aligeran en cuanto a contenido y esencia los sistemas legitimarios, de alguna forma predomina irrebatiblemente su previsión como cortapisa a la libertad dispositiva del testador en el sistema romano. Aún las Codificaciones de última generación los contemplan. Vgr. Código Civil italiano y Código Civil de Perú.

Io Cfr. De la Cámara (200I, I94).

II También aunque con mucha menor incidencia suelen calificarse dentro de este mismo parámetro como sistemas pars valoris bonorum qua in specie heres solvere debet o puramente simbólicas. 
Pars valoris: es el sistema por el que se concede al legitimario un derecho de crédito a pagar en la cuantía que se determine en la norma.

Pars valoris bonorum: es la modalidad que concibe la composición de la legítima con el valor de cada uno de los bienes que componen la herencia.

Pars bonorum: se considera en este sistema al legitimario como un destinatario forzoso de bienes más que como un sucesor, por ser considerado cotitular de los bienes del activo hereditario.

La legítima como pars bonorum parece ser posición predominante ${ }^{\mathrm{I} 2}$ en la calificación española y además muy antigua (Vallet I974, 683). No obstante, se han vertido importantes criterios totalmente opuestos ${ }^{13}$ que califican al sistema de pars hereditatis a partir de las imprecisiones gramaticales de las normas reguladoras y a la par opiniones intermedias ${ }^{\mathrm{I4}}$. Coincido con el criterio mayoritario que vincula la calificación del modelo del tipo pars bonorum a la posibilidad que franquea el artículo $815^{15}$ de satisfacer el derecho legitimario por cualquier título ${ }^{\mathrm{I} 6}$.

Restringir el contenido de la legítima a una pars hereditatis no parece admisible cuando puede ser atribuida al legitimario por concepto distinto al de herencia.

La clasificación de los sistemas legitimarios a partir de su configuración y contenido permite una completa calificación de la sucesión forzosa que cada ordenamiento

I2 Vid. Vgr. Vallet (I986, 846 (A)), Rivas Martínez (2009, I4I7), O'Callaghan $(2008,226)$ y Quince Fanjul (2008, II7). También la Dirección General de los Registros y del Notariado ha seguido este criterio de clasificación para el sistema legitimario español: Vid. Resolución de I de marzo de 2006 (RJ\2006 3919 ): «En efecto, la legítima en nuestro Derecho común (y a diferencia de otros ordenamientos jurídicos nacionales, como el catalán) se configura generalmente como una «pars bonorum», y se entiende como una parte de los bienes relictos que por cualquier título debe recibir el legitimario, sin perjuicio de que, en ciertos supuestos, reciba su valor económico o pars valoris bonorum. De ahí, que se imponga la intervención del legitimario en la partición, dado que tanto el inventario de bienes, como el avalúo y el cálculo de la legítima, son operaciones en las que ha de estar interesado el legitimario, para preservar la intangibilidad de su legitima».

${ }^{\text {I3 }}$ Vgr. Peña (I985, 864 y 865) y Ortega Pardo (I950, 342).

${ }^{\text {I4 }}$ Lacruz $($ I993, 354) sostiene que el problema de la determinación de la naturaleza jurídica de la legítima no puede resolverse mediante una solución única, las alternativas deben ser planteadas no aisladamente si no en relación unas con otras por no ser unívocas ni absolutas. Real Pérez (I988, 54 y 55) reconoce la superioridad del criterio que considera la legítima una pars bonorum, pero considera que la naturaleza de la legítima en el Código español es plural porque no puede ser pars hereditatis dada la no imposición normativa de la institución de heredero a favor del legitimario y la previsión de la posibilidad de pagar la legítima por cualquier título, tampoco pars valoris porque aunque a veces constituye un derecho de crédito, tiene garantías especiales que no le son reconocidas a ningún otro acreedor y no es por último en los casos de pago de la legítima en metálico una pars bonorum. Martín Perez (2000, I479), considera que en la calificación del sistema legitimario español en atención a su contenido, el Tribunal Supremo tiene una posición dubitativa porque la ha considerado indistintamente pars hereditatis y pars bonorum. Lledó advierte que no es fácil determinar calificación en cuanto a contenido del sistema legitimario español, porque no es clara la terminología del legislador pero pese a ello la posición predominante es que se trata en principio de una pars bonorum, Vid. Lledó Yagüe $(2002,360)$. Torres y Domínguez (20II, I842) plantean que aunque como regla pueda sustentarse que se trata de una pars bonorum, se exceptúan los supuestos contemplados en el Código español en los que se prevé el pago de la legítima en dinero, incluso extrahereditario,. La última autora $(2006,202)$ sostuvo el mismo criterio en trabajo precedente.

${ }^{15}$ En el articulado posterior al precepto, encontramos alternativas al cumplimiento del deber legitimario por título distinto al de heredero Vid. por ejemplo, artículos 8I7, 8I8, 8I9, 820.I, 82I, 822, 823, 83I. Cfr. De la Cámara (2009, 194 y ss.), Domínguez Luelmo (2010, 933) y Busto Lago (2009, 963-993).

${ }^{16}$ Ortega Pardo (I950, 342-35I) sostiene criterio distinto sobre la previsión del artículo 8I5, al estimar que existen razones de economía jurídica que procuran que los actos jurídicos produzcan siempre sus efectos normales, acudiendo sólo en última instancia a la ineficacia y esa es la ratio del articulo 8I5 del Código Civil español: evitar la ineficacia testamentaria por violaciones legitimarias sin intención de definir la naturaleza y esencia de los derechos del legitimario. 
establezca $^{\text {I7 }}$ y trasciende significativamente a la regulación de la preterición. El aspecto funcional de la sucesión legitimaria determina la utilidad de la figura de la preterición. Sólo en el sistema de reglamentación negativa, por depender la protección del cumplimiento del deber del testador, será necesaria su previsión.

\section{I.3. Necesarias distinciones}

\section{I.3.I. Notas iniciales}

Suelen trastocarse los análisis de la calificación del sistema legitimario atendiendo a su naturaleza o aspecto funcional con los tipos de sucesión y de las líneas que anteceden, quedan esbozados los presupuestos de la distinción:

Sistema legitimario es el modo en el que cada ordenamiento concibe la dinámica de la legítima, atendiendo a su aspecto funcional, a su contenido, a su aspecto formal o material y a su cuantía o extensión ${ }^{\mathrm{I}}$. Así existen como ya vimos, sistemas legitimarios romanos/pars debita o germanos/pars reservata; pars hereditatis, pars valoris, pars valoris bonorum, pars valoris bonorum qua in specie heres solvere debet, pars bonorum o puramente simbólicas.

Forma de sucesión, en cambio, alude al modo en el que llega a ofrecerse la herencia sea a través de delación voluntaria en sus modalidades contractual o testamentaria, de delación legal que dimana de la norma y de delación legitimaria que en el sistema legitimario germano dimana siempre de la norma pero en el romano según se cumpla o no el deber de legítima por el testador tendrá la voluntad o la ley como fuente.

Por ser la vigencia de una forma de sucesión propiamente legitimaria el aspecto más polémico de la construcción teórica objeto de análisis, se esbozarán los pilares fundamentales sobre los que se sustenta.

\footnotetext{
${ }^{17}$ Las codificaciones europeas, en su mayoría integrantes del modelo jurídico continental, adoptan diferentes sistemas legitimarios en atención a su contenido, de modo que confluyen ordenamientos que regulan la legítima y otros la reserve. Como ocurre en España, la terminología y en general el régimen jurídico que el legislador les confiere impide su nítida catalogación. En Francia rige un sistema de reserve al amparo de los artículos 724 y I004 del Código Civil que autores como De la Cámara (20II, I92), Rivera (I994, 4I6), Real Pérez (I988, 26, 44 y 45) y García Moreno (2008, 6I4), insertan en el modelo legitimario del tipo pars hereditatis o germano. En cambio Rentería Arocena (2OII, 2II2) la concibe del tipo pars bonorum y Cámara Lapuente (2003, I222) la inserta también en el sistema romano. La reciente reforma legislativa en ese país que se produce por la Ley 728 de 23 de junio de 2006 debilita la fuerza de la reserve al suprimirla a favor de los ascendientes y reducirla para los descendientes, Vid. (Miquel, 2009, 495). En Alemania a la pflichtteil se le concibe como una pars valoris porque se configura como obligación a la que se da cumplimiento luego de las deudas de la herencia pero antes que los legados y cargas modales. Cfr. (Röthel 2008, 54). El sistema legitimario italiano, adopta una variante de difícil calificación bajo el acápite de la sucesión necesaria. Zaccaria $(2008,69$ y ss) afirma que cuando el legitimario ejercita las acciones de reducción contra las disposiciones testamentarias, no hace valer su calidad de heredero sino un derecho propio y más, cuando ejercita las mismas acciones para reducir donaciones, ni siquiera adquiere la condición sucesoria, por lo que en aquel contexto la llamada sucesión necesaria no siempre se traduce en un fenómeno sucesorio. Vid. García Moreno (2008, 6I5). No obstante parece configurarse la legítima como una pars bonorum, Vid. Rentería (20II, 2II4). Holanda, según Miquel (2009, 495) transitó del modelo que concibe a la legítima como una pars hereditatis al que la establece como una pars valoris, asemejándose con ello a la legislación alemana a partir de la Ley de Reforma de I de enero de 2003. Esta divergencia se manifiesta también en las codificaciones latinoamericanas, aunque en ellas predomina la regulación del sistema cuyo contenido es una pars bonorum, Vid. Vgr. artículo iı8ıdel Código Civil de Chile, I059 del de Bolivia, 884 del de Uruguay, 359I y 3593 del de Argentina, I229 y siguientes del de Ecuador, I239 del de Colombia. En cambio parecen seguir el modelo de contenido pars hereditatis los artículos 723 y siguientes del Código de Perú y 883 y siguientes del de Venezuela.

I8 Estos dos últimos indicadores de calificación no han sido desarrollados en este trabajo, dada la poca trascendencia que se les atribuye pero que sí los reconoce la doctrina. Vgr. Pérez Gallardo $(2004,240)$.
} 


\section{I.3.2. Presupuestos distintivos de la «sucesión legitimaria»}

La legitimaria es sin dudas una tercera forma de sucesión, distinta de la testada e intestada porque se viabiliza a través de una delación propia o independiente y no por ello califica como de reserva legal un sistema legitimario. Además se presenta con contenido, efectos, nomen y fundamentos propios y muy distintos a los de las sucesiones testada e intestada ${ }^{\mathrm{I} 9}$.

\section{I.3.2.I. Delación}

Existe una delación legitimaria autónoma que individualiza este tipo de sucesión. En los casos de cumplimiento del deber de legítimas el llamamiento surge de la voluntad del testador y en los casos de incumplimiento dimana de la norma, pero no llega a ser ni voluntaria ni legal. Aunque coexiste con una $u$ otra presenta las siguientes atipicidades:

- Opera de distinto modo según se trate del modelo de legítimas de reglamentación negativa o del de reserva legal:

I. En el de reglamentación negativa o de freno, vocación y delación manan de un límite legalmente establecido a la libertad de testar. De forma natural dimanan del cumplimiento del deber de legítimas (o sea de la voluntad del testador) y de forma impuesta del ejercicio exitoso de las acciones protectoras de la intangibilidad cuantitativa de la legítima (de la ley). En el de reserva legal o germano vocación y delación legitimarias se producen ipso facto con la muerte del causante y proceden directamente y en todos los casos de la ley.

2. En el de reglamentación negativa o romano nunca la delación tiene un contenido atributivo directo ${ }^{20}$ sino de mero llamamiento mientras que en el sistema germano con la delación legitimaria a la vez que se ofrece se atribuye directamente. Así, en el sistema de reglamentación negativa si se cumple el deber legitimario por el testador vía mortis causa, la delación se concreta únicamente con la vigencia de un título sucesorio sin viabilizar la atribución legitimaria que deberá verificarse mediante negocios jurídicos de adjudicación posteriores. De cumplirse íntegramente este deber mediante actos inter vivos, no tendría lugar la delación forzosa, porque nada deberá adquirir por causa de muerte el legitimario. En cambio de incumplirse dicho deber y vulnerarse en todo en parte los derechos de los legitimarios, en este sistema la delación adecuada debe producirse a partir de la firmeza de las resoluciones judiciales que estimen las acciones de defensa, sin que con ello se produzca atribución alguna.

En este sentido ha dicho Vallet (I986, 835 y ss. (A) y I972, I2) que en el sistema de reserva legal la adquisición de la legítima se produce automáticamente mediante una vocación legal forzosa que no requiere aceptación, mientras que en el sistema de reglamentación negativa la adquisición de la legítima discurre por vías diferentes ${ }^{2 \mathrm{I}}$ :

19 Resulta muy interesante el criterio de Ortega Pardo (I950, 359) al estructurar las peculiaridades de la sucesión forzosa, con la intención no de demostrar su independencia sino de indicar las peculiaridades que cobra el legitimario desde su condición de heredero. Advierte como particularidades las relativas al título de la sucesión, a la composición de la cuota legitimaria, al cálculo de su cuantía, a las acciones de defensa de los derechos legitimarios, a la imposibilidad de actuación volitiva del causante en la determinación de estos sucesores y a su específica finalidad.

${ }^{20}$ Sin embargo, Ortega Pardo (I950, 349), sin negar la configuración de reglamentación negativa que tiene el sistema legitimario español, considera que en su regulación la legítima es atribuida directamente por la Ley a título de herencia. Cfr. también Peña (1985, 865).

${ }^{2 \pi}$ Vallet (I972, 6-9) afirma, sin embargo, que la legítima como conjunto de derechos que aseguran al legitimario su adquisición procede ciertamente de la ley no sólo en cuanto a su cuantía sino también a su 
- La adquisición del derecho(s) a la legítima dimana ope legis, surge ipso iure al fallecer el causante.

- El surgimiento concreto del derecho para asegurar y obtener el contenido efectivo al cual da derecho sólo surge concretamente cuando por incumplimiento por el causante de su deber de otorgar las legítimas a su respectivo destinatario o de respetarla, se produce su respectivo supuesto de hecho. Así nacen los derechos de impugnación por causa de preterición, desheredación injusta, inoficiosidad cualitativa o cuantitativa y los derechos de reclamación del suplemento, de rescisión de donaciones inoficiosas, etc.

- La adquisición del contenido material de la legítima puede derivar de uno o varios actos dispositivos del causante -inter vivos o mortis causa-o bien subsidiariamente de la ley, praeter o contra tabulas; y en este último caso, es hecho efectivo a consecuencia del ejercicio con éxito de los correspondientes derechos de impugnación o reclamación ${ }^{22}$.

- Esta tercera forma de delación a diferencia de las otras dos, opera como límite a la libertad de testar en los sistemas pars debita y en consecuencia difiere la titulación sucesoria por la que se produce el llamamiento al heredero forzoso según se haya cumplido o no el deber de legítimas por el testador:

I. Cuando el legitimario ha sido protegido por el testador, el título sucesorio en virtud del cual se inviste de la condición de sucesor (imprescindible en el modelo sucesorio romano dados los presupuestos para que opere la sucesión mortis causa) es el testamento en el que ha sido instituido por cualquier título ${ }^{23}$ pero el contenido de su derecho dimana de la ley y no de la voluntad del causante, quien en virtud de la anterior se encuentra obligado a satisfacerlo. En la sucesión propiamente testamentaria en cambio, los sucesores heredan exclusivamente por la voluntad del testador tanto en el quantum como en el nomen, es decir no hay sino margen a la voluntad del causante para la ordenación de quién y cuánto hereda. Por su parte, en la sucesión intestada es únicamente la norma, la que dispone el contenido y los sucesores. Se mezclan entonces, para formar un tipo de sucesión diferente, elementos de las anteriores de modo que: en la sucesión legitimaria la voluntad del testador se limita por la norma a efectuar o no el llamamiento, pero nunca tiene cabida en cuanto a su contenido y por ello una vez agotado el margen volitivo (se cumpla o no el deber legitimario), es la norma la que determina el curso de la sucesión ${ }^{24}$.

2. Cuando el legitimario ha sido preterido, debe concebirse que el título sucesorio que le permite investirse de la condición es la sentencia firme que estima la acciones por preterición y luego al igual que en el caso del legitimario protegido, el contenido de su derecho dimana de la norma. En este caso tanto la delación como su contenido proceden de la ley limitando la libertad de testar. Por su parte, cuando el legitimario resulta lesionado, pero no preterido, entonces su titulación sucesoria dimana en parte de la voluntad del causante, conforme al apartado que antecede, y en parte de la ley como ocurre con el preterido. No por ello se trata entonces de una sucesión legal, porque en la legitimaria el ordenamiento jurídico deja margen a esa intervención de la voluntad del causante en el sentido de elegir el modo en el que se va a desplegar la protección (por actos inter vivos o

contenido y es así que nace de ella y no de la voluntad del causante, cualquiera sea el sistema legitimario de que se trate.

${ }^{22}$ Cfr. también Vallet $(1972,5)$.

${ }^{23}$ Nótese que también puede haberse satisfecho la legítima por actos inter vivos de modo que en estos casos el título por el que se dio cumplimiento al deber legitimario se identifica con el negocio jurídico realizado por el testador lucrativamente a favor del legitimario (donación, cesión, condonación, etc.)

${ }^{24}$ González Palomino afirma que no es obligación del testador atribuir beneficio alguno al legitimario cuyo derecho no deriva del testamento, sino de la ley; vid. (Rivera I994, 224). 
mortis causa a través del cumplimiento del deber propio de legítima o de la institución de heredero o legatario $)^{25}$.

Visto de este modo, es posible afirmar que si bien en la sucesión legitimaria el estatus jurídico-sucesorio de legitimario depende de la voluntad del causante, ello es sólo en lo relativo a la especificación del título por el que se satisface su derecho, pero en cuanto a $\mathrm{su}$ contenido no tiene intervención alguna la voluntas testatoris, porque dimana íntegramente de normas de ius cogens.

La asimilación de los planteamientos anteriores no ha sido nada pacífica.

En varios interesantes trabajos, Vallet y Peña abordan el tema con la óptica que identifica al tipo de sucesión con el tipo de sistema legitimario. Vallet (I986, 834 (A)), en crítica a un trabajo precedente de Peña $(1985,849)$ en el que este autor planteaba que la legítima regulada en el Código Civil «produce un llamamiento forzoso» a los legitimarios, afirma que según ese criterio la legítima que regula el ordenamiento español responde a los caracteres de la denominada legítima germana: delación legal forzosa a título de heredero. Califica este análisis de simplista sin llegar a ser justo ni práctico, por su falta de flexibilidad. Concluye que «la legítima es una institución formada en la historia, como todas las del derecho privado, modelada en la vida, puesta en contacto leyes y práctica jurídica, que las ha interpretado y adecuado en su aplicación, para ajustar la voluntad del testador ley de la sucesión- y la protección de los justos intereses de los legitimarios, mientras que la significación de un artículo no viene definida únicamente por su texto, sino por sus antecedentes morfológicos y funcionales, por su contenido histórico presente y decisivo para el redactor, de modo que el fenómeno hereditario hay que referirlo al ciclo de significaciones precisas que ha tenido durante siglos» ${ }^{26}$.

Vallet (i986, 44 (B)) en un trabajo anterior, había dejado claro que sería chocante que por el sólo hecho de otorgar menos al preterido, en una reforma en la que redujeron los efectos de la preterición intencional, su atribución intestada, consecuente con la invalidación de la institución de heredero, se hubiese transformado no en una atribución intestada menor, sino en una delación legal forzosa, la que no operaría como consecuencia y complemento de la invalidación sino como un preexistente llamamiento directo e inmediato ${ }^{27}$.

Ambos, como otros autores, aunque con posiciones encontradas, debaten la existencia de delación legitimaria propia a partir de su traspolación a otro modelo o sistema legitimario. Se muestra convincente la posición de Vallet al refutar la protección de los derechos de los legitimarios lesionados a partir de la concepción germánica de la legítima en el contexto del derecho español y puede añadirse que es incluso forzado y desprovisto de antecedentes que lo justifiquen y de elementos contundentes en el orden teórico. Sin embargo, cosa distinta es la concepción de la dinámica de la sucesión legitimaria en este contexto y cuando se pierde de vista esta distinción, el análisis resulta circundante y muy poco productivo. Nótese como en la última cita, este autor descarta la posibilidad de que se viabilice la atribución legitimaria mediante la titulación que resulta de las acciones de invalidación, pero sólo por trastocarlo con el llamamiento legal o directo.

\footnotetext{
${ }^{25}$ Téngase en cuenta, sólo como un elemento más, que los artículos 8I5 y 494 de los Códigos Civiles cubano y español respectivamente, admiten la satisfacción de la legítima por cualquier título y con tal regulación lejos de excluirse, el título legitimario per se ha de entenderse comprendido.

${ }^{26}$ Vallet (I982, 53I) descartó también la autonomía de la sucesión legitimaria en las legislaciones forales.

${ }^{27}$ Vallet $(\mathrm{I} 973,40)$ niega también la autonomía de la delación forzosa en los ordenamientos forales.
} 
Otras voces niegan también la autonomía de la delación forzosa, algunas con el mismo afán de sostener su inviabilidad en el sistema legitimario de reglamentación negativa o de freno ${ }^{28}$ y otras con diversos argumentos ${ }^{29}$.

En cambio, otros autores se refieren a la autonomía de la delación forzosa, partiendo de la interpretación de los artículos 806 y 807 del Código Civil. Según Peña $(\text { I } 950,863 \text { y ss. })^{30}$, el Código Civil regula un especial llamamiento de herederos, diferente al voluntario y al intestado, pues se funda sólo en la ley pero no es supletorio, sino forzoso, es un llamamiento general primario y estas diferencias existen no sólo en la forma de producirse los llamamientos sino también en su régimen. Asimismo dejó claro que no siempre se produce por el imperio legal, sino también por el cumplimiento del deber legitimario, o sea por voluntad del causante. En la misma línea González Collado (i946, 540 y 54I) afirma que el legitimario en España no precisa un «ius abstenendi» su adquisición ipso iure es sólo de activo y no puede acarrearle perjuicios. Adquiere y no sucede; por eso no es necesario un tercer tipo de delación: la forzosa, porque esta adquisición ex lege no es que se imponga a la voluntad del causante, sino que no la toma en consideración. Estos autores se aproximan bastante a la concepción de la independencia de la delación legitimaria sólo que sus puntos de partida se ubican también en la regulación del sistema germano en el Código Civil español. Ofrecen un análisis que estructura este llamamiento del tipo legal forzoso y con ello se debilitan sus argumentos porque se ha visto que la delación legitimaria, si bien estará determinada en todos los casos por su carácter forzoso, no siempre tendrá como fuente a la ley.

Lacruz (I993, 354, 364 y 365) estima que hay tres supuestos en los cuales cabe hablar de verdadera vocación legitimaria, distinta a la testada e intestada porque el llamamiento opera a favor de los legitimarios afectados y no de los restantes sucesores legales. Los supuestos que enumera este autor son:

a) En los casos de protección parcial, en los que tiene el perjudicado derecho a recibir el complemento de su porción por ley y contra el testamento.

\footnotetext{
${ }^{28}$ Vgr. Alguer (I93I, I32 y SS.) plantea que la delación puede tener tres causas diferentes: la testamentaria, la contractual, allí donde se admite, y la legítima y que el llamamiento forzoso sino es más que un límite puesto al llamamiento voluntario. Albaladejo $(2008$, 9) sostiene igualmente que la sucesión legitimaria generalmente no funciona como otra nueva forma de adquirir los bienes junto a la testada e intestada, sino sólo como un límite a la libertad dispositiva del causante de modo que únicamente se adquieren por sucesión forzosa cuando no se respeta la legítima y por tanto el testamento es invalidado en cuanto la viole, adquiriendo los legitimarios la legítima en ese concepto de sucesión forzosa. Rivas (2009, I4I2) afirma que el Código Civil español sigue un sistema legitimario de freno y no regula como un modo de adquirir por herencia a las legítimas, sino que asegura a los legitimarios imponiendo a las facultades dispositivas del causante una pluralidad de limitaciones legales y relativas a fin de que los parientes íntimos y su cónyuge, puedan recibir del patrimonio o de la herencia, determinada cuota o un usufructo respectivamente, bien por donación o por disposición testamentaria del causante, bien por sucesión intestada abierta en defecto de testamento o por ineficacia de sus disposiciones, pero no la atribuye directamente por una tercera vía sucesoria

${ }^{29}$ Claude Chifflet señaló que con la legítima no se trató de establecer una delación legal de la cuota, sino de determinar cuál era cuantitativamente la cuota debida (Vallet, I974, 684). Polaco niega la autonomía de la sucesión forzosa por entender que las legislaciones modernas no conciben a la sucesión necesaria en el sentido romano de la adquisición ipso iure de la herencia aún en contra de la voluntad del heredero (Ortega Pardo, I950, 358). García-Bernardo Landeta sostiene que la sucesión forzosa de los legitimarios no es en el Código Civil español un tercer modo sucesorio de adquirir, que haya de agregarse a la sucesión testamentaria e intestada, pues el artículo 609 desconoce que la propiedad y los demás derechos reales se adquieren y transmiten por un tercer género sucesorio distinto de la sucesión testada e intestada, que son los dos únicos modos de adquirirlos por vía sucesoria que regula (Rivas, 2009, I4I2).

$3^{\circ}$ Peña (I950, 870-873) como fundamento de orden histórico, agrega que el legislador español no se inspiró en el romanismo de las partidas sino en el Fuero Juzgo, Fuero Real y Leyes de Toro que establecieron la legítima tal cual ha llegado hasta nosotros. Enumera este autor ocho elocuentes supuestos en los cuales se patentiza el carácter forzoso y especial del llamamiento legitimario, porque prevalece en ellos el régimen jurídico de la sucesión forzosa con independencia del que corresponde a los llamamientos testamentarios o legales supletorios.
} 
b) En el caso de desheredación injusta en el que se llama por ley al desheredado en concurrencia con el llamamiento voluntario a los restantes sucesores.

c) En los casos de preterición intencional, según establece el artículo 8I4 del Código Civil español, porque se reducen las disposiciones testamentarias y se produce a favor del preterido un llamamiento legal contra el testamento -sucesión forzosa- idéntico al del injustamente desheredado.

Concluye este autor en análisis interpretativo del artículo 806 del Código Civil español, que si el testador no puede disponer de la legítima, evidentemente el llamamiento a la misma procede sólo de la ley y que así lo confirma el precepto al explicar la causa de la indisponibilidad de modo que concibe una reserva, una atribución directa.

En otros estudios ${ }^{3 \mathrm{I}}$ se aborda el tema sin tomar partido entre una $u$ otra alternativa pero inclinándose hacia la autonomía de la sucesión forzosa desde distintos ángulos.

\section{I.3.2.2. Contenido}

El contenido de la legítima está integrado, según lo posibiliten las codificaciones nacionales por una porción alícuota y sólo activa del patrimonio reconstruido del causante, de modo que para su debida composición no son suficientes los activos que existen tras su muerte, sino que se imputan a estos valores el de las posiciones jurídicas activas de las que en vida fue titular el causante, siempre que sean transmisibles mortis causa y aunque hubieren sido enajenadas gratuitamente mediante actos inter vivos por el testador.

De esta forma la magnitud de la sucesión legitimaria se extiende sobre cierta porción transmisible del patrimonio del causante aunque ésta no se haya convertido en herencia, lo que sintoniza con el fundamento de este tipo de sucesión y le aleja notablemente del contenido de las sucesiones testada e intestada cuya integración es idéntica y se produce únicamente a partir de la conformación de la herencia, sin expectativa alguna de inclusión de bienes, derechos o acciones anteriores del causante.

Plantea Lacruz $(1973,33)$ que aunque la sucesión universal y el derecho del legitimario se expresan en partes alícuotas de un todo, se trata en cada caso de un todo absolutamente diferente.

\section{I.3.2.3. Sujetos}

Legitimarios, herederos forzosos, herederos especialmente protegidos, donatarios, cesionarios, beneficiarios, según se acepte o no por título distinto al sucesorio, son algunos de los nombres de los destinatarios de la legítima. Aunque pudiera presentarse como un elemento poco trascendente en el análisis que se viene hilvanando, si se atiende al contenido de estas instituciones sí que trasciende como nota distintiva con respecto a las sucesiones testadas e intestada. En estas últimas los causahabientes serán siempre sucesores mortis causa a título de heredero o legatario según el caso, cuyos contenidos son invariables. En cambio en la sucesión legitimaria los causahabientes aunque son siempre

\footnotetext{
${ }^{3}$ Vgr. Miquel $(2003,536$, (B)) afirma que lo que falta en caso de preterición no es un título sucesorio al heredero forzoso preterido porque la ley se lo da, sino al testamento una declaración de voluntad testamentaria, que la ley exige al testador como carga formal para garantizar que tome en cuenta a los hijos o descendientes legitimarios, que además de legitimarios son herederos ab intestato de primer orden y grado y Quince Fanjul $(2008$, II9) señala que tras la reforma legislativa de I98I en España, la regulación actual en sede de preterición avanza con respecto a la anterior pues tras la nulidad de la institución de heredero en cuanto afecte a la legítima se abre la sucesión legitimaria y se crea un nuevo título de imputación sucesoria.
} 
legitimarios, pueden ver satisfecho su derecho a título propiamente legitimario, de herencia, de legado o de beneficios que le haya dispuesto inter vivos el causante. Las particularidades de la institución de heredero o legatario a favor del legitimario, son ajenas a estas instituciones en las sucesiones testada e intestada.

Algunos autores españoles han concebido la ubicación subjetiva del legitimario como herederos a partir de la interpretación del artículo 806 del Código Civil, siguiendo el criterio interpretativo gramatical, mientras que otros guiados por una exégesis integradora, advierten las notables diferencias entre los sujetos beneficiados con la sucesión forzosa y los herederos. En la primera posición ${ }^{32}$ se les concibe como herederos con el argumento fundamental de que ningún análisis de la doctrina moderna puede negar la condición legal del legitimario. En cambio estiman distinto estado de la cuestión otros autores, sobre la base de la imprecisión terminológica del indicado precepto al llamarlos herederos forzosos, la que se patentiza con la posibilidad de satisfacer la legítima por cualquier título y con la no responsabilidad por deudas del causante a cargo de los legitimarios, previstas en los artículos 8I5 y 8I8 respectivamente del mismo cuerpo legal. En este grupo no ha sido uniforme la calificación de estos sucesores ${ }^{33}$.

En el presupuesto subjetivo de la sucesión legitimaria, se inserta la polémica -sin equivalencia en las sucesiones testada e intestada- en cuanto a los derechos que le asisten al legitimario a partir de la muerte del causante en tanto adquiera lo que por legítima le corresponde, cuando la adquiere por título distinto al de heredero. Como plantea Lacruz $(1973,37)$, se discute con fuerza si la condición de legitimario reporta a su titular derechos superiores a los que comporta el título sucesorio elegido por el legitimario. La discusión pasa en lo fundamental por la controversia de si en estos casos resulta titular de la posesión civilísima, teniendo en cuenta que no hay una titulación sucesoria hereditaria.

$\mathrm{Al}$ parecer Vallet $(\mathrm{I} 978,46)$ considera que no, cuando al admitir que aunque con la regulación actual del Código Civil español no es necesario instituir heredero al legitimario, sólo a favor de aquellos es que subsisten las ventajas derivadas del hecho de poder ocupar por propia autoridad la cosa asignada, de adquirir ipso iure la posesión civilísima otorgada por el artículo 440 del Código Civil español y de gozar de la misma protección posesoria que el heredero.

32 Vgr. Ortega Pardo (I950, 36I) considera al legitimario irrefutablemente heredero por imperativa atribución legal de esa condición, aunque venga matizada por una serie de peculiaridades y protegida con unas garantías específicamente establecidas para asegurar el fin especial de la sucesión forzosa, así lo afirma a pesar del criterio de determinación de la sucesión a título universal para la institución de heredero, por entender que el heredero forzoso constituye una excepción a esta regla. Vid. Peña (I985, 850 y Ss).

33 Roca Sastre y Puig Brutau (2009, I88 y I89) consideran que cuando el Código Civil español habla de herederos forzosos en lugar de legitimarios incurre en una imprecisión terminológica que no debe perjudicar la doctrina que él mismo desarrolla y que la concepción de la legítima como derecho a una parte alícuota del saldo activo de la herencia permite reforzar la doctrina del legado de parte alícuota. Lacruz $(1993,365)$ afirma que el legitimario es muy peculiar porque en cuanto tal está dotado de poderes que le constituyen en un súper sucesor al poder reclamar en la herencia una participación superior a la que le asignó el causante, cuya voluntad aquí es rectificada y contradicha, pero sobre todo pudiendo reclamar bienes o valores que ya no están en el patrimonio del causante, pero que salieron de él en perjuicio de sus derechos, así el legitimario, cualquiera se la terminología legal, es una persona que tiene derechos sobre el patrimonio del causante. Albaladejo $(2008,377)$ plantea que la terminología de llamar herederos forzosos a los legitimarios es inexacta porque pueden ser también donatarios, legatarios, etc. Espejo (I996, 370 y 37I) afirma que la condición de legitimario modifica algunas consecuencias de la titulación de este tipo de sucesor: si es legatario modifica las normas de prelación entre legatarios; si es heredero modifica su responsabilidad ante reclamaciones de la legítima de otros legitimarios en la medida en que afecte a su propia legítima, también su responsabilidad en legados y por deudas ordinarias, tampoco siendo heredero queda el legitimario vinculado a los actos del causante lesivos de su derecho. Torres García (2009, 315) los considera propiamente legitimarios. Vid. párrafo 2079 del BGB que acoge la posición de considerarlos simplemente legitimarios resaltando la importancia patrimonialista de la institución. 
Finalmente considero que el legitimario es un sujeto del Derecho de sucesiones, con regulación normativa propia obedeciendo a la satisfacción de una necesidad social y se yergue como categoría independiente con contenido determinado integrado por un conjunto de acciones de defensa de su derecho que le son inherentes y reconocidas en exclusiva.

\section{I.3.2.4. Efectos}

La sucesión forzosa tiene efectos positivos, como las otras dos que son respecto al causante los referidos a la posibilidad de determinar el modo en que da cumplimiento a su deber legitimario como manifestación del principio de libertad de testar y respecto a los legitimarios están referidas a la posibilidad de adquirir la legítima. También produce efectos negativos, que a diferencia de los primeros son exclusivos de esta forma de sucesión y se producen cuando se vulneran en todo o en parte los derechos legitimarios a través de las atribuciones insuficientes, las desheredaciones injustas o las pretericiones. Para cada uno de estos supuestos prevén los ordenamientos jurídicos un conjunto de acciones protectoras $^{34}$, que resultan de vital importancia a la hora de calificar el sistema legitimario de que se trate.

\section{I.3.2.5. Fundamento}

La sucesión testamentaria tiene como único fundamento la voluntad del causante y la intestada traslada este fundamento ajustado al respeto a la presunta voluntad del causante sumado al general de la necesariedad del derecho de sucesiones. En cambio la sucesión legitimaria, según ha ido evolucionando ha ido ajustando su fundamento pero ha conservado siempre su esencia ética, protectora de la familia primero con más fuerza patrimonialista y luego social. En la actualidad se va trasladando el sostén de este tipo de sucesión a la función asistencial con la que algunos ordenamientos, como el cubano ${ }^{35}$, ya lo conciben deviniendo en importante tutela a la incapacidad, la discapacidad y la minoridad (Pérez Gallardo 2009, 736).

\section{I.3.3. Precisiones finales}

Va quedando clara la distinción entre las categorías tipo de sucesión -en cuanto a la legitimaria se refiere- y sistema legitimario. El sistema legitimario, permite concebir el funcionamiento de la sucesión legitimaria de modo que existe entre ambas categorías una relación interactiva a modo género (sucesión legitimaria) -especie (sistema legitimario) pero nunca de equivalencia.

Pueden colegirse además los presupuestos distintivos de la sucesión legitimaria a la que en cada ordenamiento civil corresponderá un sistema legitimario cuya identificación permite determinar su funcionamiento ${ }^{36}$. Como tipo de sucesión, se integra siempre a la testamentaria o a la intestada, porque a diferencia de estas últimas, no opera nunca en exclusiva, sino en el contexto de una u otra según haya cumplido o no su deber legitimario

\footnotetext{
34 Vgr. Acciones de nulidad y de suplemento entre las que se encuentran acciones de reducción y de rescisión cada una concebida en función de la extensión de la lesión legitimaria.

35 Vid. infra epígrafe II.I

${ }^{36}$ Por ejemplo, la sucesión legitimaria en Cuba pertenece al sistema romano o de reglamentación negativa o de freno y es a su vez de tipo pars bonorum. Con independencia del modelo del que se trate, igual calificación puede hacerse en todo ordenamiento jurídico que conciba las legítimas.
} 
el testador. A las ya vistas distinciones se adicionan un conjunto de instituciones propias de este tipo de sucesión como la mejora, el derecho al suplemento, la desheredación ${ }^{37}$ y el funcionamiento del acrecimiento sucesorio (Peña, I985, 866 y 867).

La independencia de la legitimaria como forma de sucesión, no obedece a criterios injustificados ni mucho menos intrascendentes. Por el contrario, resulta sustentable en el orden técnico a partir del esbozo de los argumentos anteriores y trasciende a una protección más efectiva de los derechos legitimarios, que en el contexto de los sistemas romanos -por operar como límite a las libertades del testador y no como forma de atribución directarequieren un replanteamiento urgente.

Rivera Fernández (I994, 4I5 y 4I6) afirma en este orden de ideas que «... lo más razonable sería definir la situación jurídica del legitimario. Con ello se simplificaría enormemente la posición de los herederos forzosos en el ámbito de los conflictos sucesorios». Añade que si optamos por crear un nuevo título sucesorio, como puede ser el de simplemente legitimario, debemos dotarlo de contenido, al igual que ocurre con los títulos de heredero y legatario, pero en ningún caso dejar apuntada su creación, como hace el párrafo primero del artículo 8I4 del Código Civil español, y seguidamente no configurar su régimen jurídico.

En efecto, la autonomía del título sucesorio legitimario, requiere la regulación de su contenido, pero parece ya hecho en la propia norma cuando regula el contenido de la legítima, identifica a los legitimarios y establece sus acciones de defensa.

A igual conclusión arribó Espejo (1996, 363, 369 y 370) al afirmar que la naturaleza de la legítima puede concebirse como título sucesorio con consecuencias propias que no excluye la existencia de otro título, sucesorio o no, a favor del legitimario y que le otorga una posición sucesoria no asimilable a ninguna otra. Concluye que este título sucesorio funciona autónomamente para impugnar los actos lesivos de la legítima y luego justificar la adquisición de la porción que corresponde a los legitimarios ${ }^{38}$.

La mayoría de las codificaciones latinoamericanas debieron estar impregnadas por este criterio de independencia de la sucesión forzosa al articular el sistema de efectos de la preterición a partir de su adquisición directamente derivada de las acciones de impugnación de los actos violatorios de su derecho, sin preverse la nulidad testamentaria.

Los artículos 467 y 509.I y 2 del Código Civil Cubano y 658, 912.I y 2 del español ${ }^{39}$ no constituyen verdaderos obstáculos porque ${ }^{40}$ :

37 Nótese que también tienen instituciones y principios propios las sucesiones testadas e intestada, que coadyuvan a sus autonomías; Vgr. legado, sublegado, sustitución, revocación, albaceazgo, etc. y representación, principio de exclusión de grados, etc., respectivamente.

${ }^{38}$ En la doctrina española se han producido otros acercamientos al tema. Vgr. Lacruz (1973, 35-37 y I993, 354 , 364 y 365) y Torres García y Domínguez Luelmo (I950, I850) lo han abordado sólo en los supuestos de violaciones legitimarias, «...cuando el testador cumple con su deber legitimario no hay por qué utilizar las medidas de freno en que consiste la legítima, por lo que no se puede decir que exista una forma singular de suceder: los legitimarios serán herederos, legatarios o donatarios dependiendo de la voluntad del causante, ... pero cuando existe inoficiosidad la atribución de bienes en la medida del perjuicio sufrido se produce en virtud de un llamamiento legal...». En trabajo precedente Torres García (2006, I90) coincide con el criterio de De La Cámara (20II, I99), en cuanto a que se produce una delación legitimaria autónoma en los supuestos de la legítima del cónyuge viudo, pero este último autor la niega en el resto de los casos. Estima además Torres García $(2009,305)$, que la Reforma que introduce la Ley is de I3 de mayo de I98I a los preceptos del Código Civil avala la autonomía de la sucesión forzosa.

39 Del Código Civil cubano:

Artículo 467: r.La sucesión tiene lugar por testamento o por ley. La primera se denomina testamentaria y la segunda intestada. 2. La herencia puede trasmitirse también en parte por testamento y en parte por disposición de la ley. 
- Los artículos 467 y 658 son reguladores de los tipos de sucesión dispositivamente, pero omiten a la sucesión legitimaria como tercera forma de sucesión sin que sea esta omisión invalidante, porque en artículos posteriores (492 al 495 del Código cubano y 806 y ss. del español) se regula de forma específica, por lo que resulta enteramente viable en ambos ordenamientos. En el caso de Cuba, se vislumbra una situación paralela en el caso de la imprevisión del contenido atípico testamento en la correspondiente norma de carácter general (Vid. artículo 476) y luego en otros específicos se regulan particulares atipicidades en las disposiciones testamentarias (Vgr. artículo 469 apartado 2)

- Los artículos 509 y 9I2 son enunciativos de la apertura de la sucesión intestada. No impiden nada, sólo viabilizan su procedencia sin que pueda estimarse que se encuentran formulados bajo el sistema de númerus clausus. Por el contrario se muestran como el resto de los preceptos informados por el método normativo dispositivo propio del Derecho Civil. Se puede entender que omiten en sus apartados primeros la excepción de la nulidad de la cláusula de institución de heredero operada por preterición, tras lo cual sólo se debe abrir la ab intestato cuando satisfecha la legítima y cobrados los legados, si los hubiere, quedare aún herencia por transmitir. No previsto a las claras por el legislador, interpretarlo pudiera quebrantar el viejo dogma que prohíbe al intérprete distinguir cuando la norma no lo hace, pero si se analizan todos los elementos anteriores no podrá considerarse contundente este inconveniente.

Artículo 509: La sucesión intestada tiene lugar cuando: a) Una persona muere sin haber otorgado testamento, o este se declara judicialmente nulo o ineficaz en todo o en parte; b) el testamento no contiene institución de heredero en todo o en parte de los bienes, derechos y acciones, o no dispone de todos los que corresponden al testador. En este caso, la sucesión intestada tiene lugar solamente respecto de aquellos de que no hubiera dispuesto.

Del Código Civil español:

Artículo 658: La sucesión se defiere por la voluntad del hombre manifestada en testamento, y, a falta de éste, por disposición de la ley. La primera se llama testamentaria y la segunda legítima. Podrá también deferirse en una parte por voluntad del hombre, y en otra por disposición de la ley.

Artículo 9I2: La sucesión legítima tiene lugar: I. Cuando uno muere sin testamento, o con testamento nulo, o que haya perdido después su validez. 2. Cuando el testamento no contiene institución de heredero en todo o en parte de los bienes, o no dispone de todos los que corresponden al testador. En este caso, la sucesión legítima tendrá lugar solamente respecto de los bienes de que no hubiese dispuesto.

${ }^{40}$ No ha sido éste el criterio seguido por Vallet (1986, 839, (A)) cuando en interpretación del artículo 658 del Código Civil español, predecesor del 467 cubano, refiere que no hay sucesión legal forzosa. Reitera el mismo autor (I986, 68, (B) y I972, I6) su criterio cuando afirma que en el régimen del Código Civil sólo existen dos formas de delación hereditaria: la testamentaria y la intestada porque así resulta de los artículos 6o9, referente a los modos de adquirir, 658 y 913, que además muestran el carácter subsidiario de la segunda respecto de la primera. En sentido contrario Peña (I985, 868 y 869) sostiene con fuerza que aunque los artículos 658, 609 y Io०9 del Código Civil español parecen contradecir la existencia de un tercer modo de deferirse la herencia, deben ser entendidos como los demás preceptos que establecen respectos de las distintas relaciones jurídicas que éstas han de regirse por el correspondiente negocio jurídico y rige lo que llama régimen primario inderogable de la relación jurídica. Estima en este orden, que la sucesión forzosa forma parte de este régimen primario inderogable y aplicable, por consiguiente, tanto cuando hay como cuando no testamento, de forma tal que:

Existiendo testamento el régimen de la sucesión viene integrado por:

a) Las normas imperativas y entre ellas las que precisan el régimen de los herederos forzosos.

b) Las normas válidas establecidas por el testador

c) Las normas dispositivas supletorias de la voluntad del testador, entre las que pueden estar las de la sucesión ab intestato.

No existiendo testamento, el régimen de la sucesión se integra por el imperativo primario de la sucesión forzosa y el legal supletorio, fundidos con primacía de las normas del primero. Similar criterio de integración con primacía ofrece Albaladejo $(2008$, 9). Lacruz $($ I973, 35 y I993, 364) sostiene de igual modo que si bien el significado de los artículos 658 y 9² del Código Civil español es innegable, el hecho de que la adquisición del legitimario no figure entre ellos como parte de los modos de suceder, no quiere decir que se opere siempre y necesariamente a través de las formas testada e intestada, sino que no existe una sucesión necesaria como regla general, ni tampoco con caracteres unitarios, en cambio sí hay supuestos en los que el legitimario adquiere los bienes que integran su legítima por vías distintas de la testada y la intestada: por obra de la ley. 
La delación legitimaria opera siempre que existen sujetos con derecho a la porción de la que el causante no puede disponer libremente, haya otorgado o no testamento. No sólo en los casos en los el testador haya incumplido su deber y por tanto no haya ofrecido titulación alguna al legitimario, si no también cuando lo atribuye. En el primer caso ha sido más valorada su utilidad y luce más nítida su autonomía. Téngase en cuenta, que aún cuando se satisface el derecho legitimario, en todo o en parte, la titulación surge de la voluntad del causante o en su defecto de la ley, pero el contenido y los efectos de ese llamamiento, están imperativamente regulados por la norma, lo que le confiere autonomía y relevancia. Es por tanto una delación compleja por la variedad de manifestaciones y de fuentes.

\section{El sistema legitimario cubano}

\section{II.I. Función asistencial de la sucesión legitimaria en Cuba}

Tras la entrada en vigor del Código Civil cubano el I2 de abril de I988 se produce un contundente viraje en la esencia de muchas de las instituciones que regula. De los regímenes legales que establece este cuerpo normativo, puede que uno de los más invadidos por la reforma haya sido precisamente el legitimario. El antecesor Código Civil español, extensivo a Cuba desde I889 y con casi un siglo de vigencia en territorio cubano, establecía un sistema de legítima con el histórico arraigo de su concepción primigenia: la preservación de una conducta ética entre las personas con vínculos consanguíneos cercanos, con trascendencia a la conservación también del patrimonio familiar dentro de la familia.

De una rápida lectura de los artículos 492 al 495, únicos dedicados al régimen que nos ocupa, pudiera pensarse en el destierro normativo del sistema legitimario en Cuba. En primer orden por la positivista simplificación de sus instituciones expresada en la reducción de los preceptos ordenadores, la omisión de figuras fundamentales y las imprecisiones de la regulación actual. También por el cambio denominativo de sus instituciones al suprimir toda referencia a la nomenclatura tradicional y sustituirla por la de herederos especialmente protegidos. Por último pudiera coadyuvar a esta aparente conclusión, la transición de la legítima cubana al régimen asistencial como fundamento de esta forma de sucesión.

Justo en esto último radica el principal viraje operado en el ordenamiento cubano a partir de I988. La influencia de las codificaciones civiles en los países de Europa del Este determinó tal estado de cosas y en este sentido afirma Pérez Gallardo $(2004,257)$ que el legislador cubano no hizo más que asimilar la preceptiva rusa, influida a su vez por otros Códigos de aquella Europa del Este. El carácter asistencial lo determina la incorporación de los requisitos de dependencia económica respecto al causante e inaptitud para trabajar como presupuestos para el despliegue de la especial protección legitimaria, conjuntamente con el requerimiento de consanguinidad o relación conyugal.

Sin embargo, como iremos viendo, estas modificaciones incorporaron nuevos matices a la sucesión legitimaria en Cuba pero sin llegar a abolir la estructura del régimen anterior. Ello lejos de constituir una ventaja, a la vez que nos permite afirmar la existencia de la regulación legitimaria en Cuba, nos coloca ante un verdadero quebradero de cabeza porque en esta concurrencia de regímenes el legislador cubano empleó hilos tan cortos que no permiten conducir una interpretación exitosa por sus longitudes que conlleven a una solución satisfactoria a partir de la ratio legis. En este sentido ha dicho Pérez Gallardo (2004, 259) que «el resultado ha sido cual un implante de órganos vitales que agudiza el estado de salud, ya quebrantado de por sí, del receptor». 
Podemos entonces afirmar que existe la previsión en el Código Civil cubano de la sucesión legitimaria en Cuba siguiendo al mismo autor (2004, 26 I y ss.) porque:

- Los herederos especialmente protegidos al amparo del artículo 492 constituyen un freno a la libertad de testar, igual que los legitimarios ${ }^{4 \mathrm{I}}$.

- Los herederos especialmente protegidos deben ser atributarios de una parte del acervo patrimonial del testador y no de una cuota en concepto de alimentos.

- La parte que corresponde a los herederos especialmente protegidos asciende a la mitad del patrimonio del causante, porción similar a algunos ordenamientos legitimarios e igual a otros.

- La cuota que corresponde a los herederos especialmente protegidos puede satisfacerse por el causante por título distinto al sucesorio.

- Como todas las normas jurídicas que tutelan en otros ordenamientos la legítima, las cubanas son de ius cogens.

El nuevo régimen, desde su mero enunciado por la norma vigente, produce interrogantes que en nada contesta el articulado, referidas en lo fundamental a la determinación del momento en el que han de ser medidos los requisitos de dependencia económica e inaptitud para trabajar; a la renunciabilidad a la condición legitimaria y a la viabilidad de las causales de incapacidad relativa o indignidad sucesoria. Cada uno de estos tópicos amerita detallados análisis, pero al sólo efecto ilustrativo se abordarán someramente a continuación.

II.I.I. Determinación del momento de valoración de los requisitos para la especial protección

$\mathrm{Al}$ respecto han sido planteadas tres posibilidades:

I. Atender al momento del otorgamiento del testamento.

2. Atender al momento de la muerte del causante

3. Hacerlo extensivo hasta el momento de la adjudicación.

El momento del otorgamiento debiera descartarse como determinativo para la medición que se analiza si se tiene en cuenta la naturaleza jurídica del testamento: negocio jurídico mortis causa y de última voluntad. Ningún efecto para terceros produce en vida del testador, impidiendo tal estado de cosas la ubicación premortem de la valoración del cumplimiento de los requisitos legitimarios.

En cambio al dilucidar el análisis entre el instante de la muerte ${ }^{42}$ y el de la adjudicación no se presentan tan absolutos los argumentos. Exigir al momento del fallecimiento el cumplimiento de los requisitos parece la tesis más adecuada. Sin embargo

\footnotetext{
${ }^{4 \mathrm{I}}$ Entre ambos sujetos la diferencia fundamental viene a ser que la adquisición de la condición de heredero especialmente protegido se viabiliza a través del cumplimiento de los requisitos de determinado vínculo consanguíneo y de dependencia económica respecto al causante por inaptitud para trabajar.

$4^{2}$ En el contexto del sistema legitimario español y en ocasión de la determinación del momento que marca la existencia preterición o su intencionalidad, varios autores, con criterios que tributan a este análisis se decantan por el momento de la muerte. Vid. por ejemplo, Lacruz (I993, 438), Rivera Fernández (I994, 225, 424-425) y Lledó (200I, 2526).
} 
no deja de preocupar el posible resquebrajamiento de la función asistencial de la protección legitimaria de nuestro ordenamiento, cuando se adjudica la porción legitimaria a quien si bien ostentaba requisitos de dependencia económica del causante al momento de su fallecimiento, ya los ha perdido en el de la adquisición. Pérez Gallardo $(2004,262)$ en este sentido ha sostenido que la finalidad tuitiva de la norma y el grado de actualidad que reclama en esas circunstancias de especial protección, también tendrían peso en la postura que se asuma en este análisis.

La Sala de lo Civil y de lo Administrativo del Tribunal Supremo cubano en cambio, no ha seguido una uniforme línea en este particular porque ha constituido argumento de sus fallos, tanto el momento de la muerte como el del otorgamiento del testamento ${ }^{43}$.

Sin embardo asumir el criterio de que el momento para la valoración de los requisitos de especial protección en el legitimario es el de la muerte resulta recomendable por las siguientes razones:

- Según el artículo 522 del Código Civil cubano, los efectos de la aceptación se retrotraen al momento de la muerte que es el que marca la apertura del iter constitutivo del derecho hereditario y la adjudicación es uno de estos efectos.

- La teoría de los derechos adquiridos permite validar la adquisición posterior de la legítima en atención a la existencia de presupuestos anteriores.

- Dado que en el interregno que media entre las acciones impugnatorias por preterición y la adjudicación de la legítima pueden extinguirse las condiciones de dependencia e inaptitud, asumir que han de perdurar hasta la adquisición conduciría a que no habría que valorarlos por el juez en el juzgamiento de las acciones por preterición o complemento. Ello desde luego, resulta incorrecto porque el cumplimiento de los requisitos para el éxito de estas acciones trasciende en el orden procesal a la legitimación. Se generaría un caótico estado a partir de la sentencia que estima las acciones de defensa anulando las disposiciones testamentarias que violan la legítima cuando se pierden los requisitos por el impugnante para poderla adquirir luego. Idéntica situación puede producirse, en lo pertinente, con el ejercicio exitoso de las acciones de suplemento. Más que al caos, se conduciría al absurdo.

\section{II.I.2. Renunciabilidad a la condición de heredero especialmente protegido}

Las discusiones sobre la renunciabilidad de la legítima en el contexto normativo cubano, rebasa los límites de los análisis que versan sobre la renuncia general a determinados derechos. Se complica por el fundamento asistencial con que se regula el derecho legitimario en el Código Civil, de tal suerte que pudiera colisionar su renuncia con su fundamento, derivando con ello en la inviabilidad de la primera.

No obstante, la deducción anterior también podría derivar al absurdo de entender que no puede el individuo renunciar a lo que necesita, olvidando que si bien las normas previsoras de la legítima tienen un carácter tuitivo y en consecuencia imperativo, también los derechos que de ellas dimanan pueden renunciarse porque no va ello en detrimento de otro sujeto o colectividad que no sea el renunciante mismo, por lo que al amparo del artículo 5 es perfectamente viable la renunciabilidad legitimaria. Téngase en cuenta que la

${ }^{43}$ Vid. por ejemplo, Sentencias de la Sala de lo Civil y lo Administrativo del Tribunal Supremo Popular No. 934 de 29 de noviembre de 1996 (momento del otorgamiento); No. I89 de 3I de marzo de 2003 y No. I80 de I5 de marzo de 2005 (momento de la muerte). 
imperatividad normativa que determina el régimen legitimario recae sobre el deber de protección y no sobre el derecho a ella ${ }^{44}$.

II.I.3. Aplicación de las incapacidades relativas o indignidades sucesorias a los herederos especialmente protegidos

Como la legítima de asistencia supone el reforzamiento del deber tuitivo del testador hacia sus legitimarios a partir de la necesidad que de esa protección presentan estos últimos, se ha debatido también la posibilidad de la incapacitación sucesoria de los herederos especialmente protegidos.

El legislador cubano sustituyó la antecesora figura de las indignidades sucesorias previstas en el Código Civil español vigente en Cuba desde I889, por las vigentes causales de incapacidades para suceder previstas en el artículo 469 del Código cubano. Se trata de una sustitución más nominativa que sustancial porque conservan las vigentes causales la misma esencia protectora de la dignificación del causante como presupuesto para la aptitud sucesoria.

Ahora bien, se suscita la controversia referida a la viabilidad de la exigencia de capacidad para suceder a los herederos especialmente protegidos a partir de su naturaleza asistencial, aunque esta disyuntiva no es exclusiva del sistema legitimario cubano ${ }^{45}$.

Pérez Gallardo en varios de sus trabajos (2004, 267 y I997, 20, (B)) ha concluido que nada impide que cualquiera de los legitimarios pudiera perder sus derechos por estar incurso en las causales de incapacitación sucesorias del artículo 469 del Código cubano, a excepción de la tercera en toda su extensión dado que sería imposible que un mismo sujeto sea de los que la ley obliga a proveer de alimentos a otro a la vez que dependiente económicamente de ese otro. Regula el indicado apartado que «son incapaces para suceder como herederos o legatarios los que hayan negado alimentos o atención al causante de la herencia».

En efecto no se advierte óbice para el control de la capacidad sucesoria de los legitimarios ni siquiera bajo el imperio de la sucesión forzosa prevista en Cuba, teniendo en cuenta que si bien se refuerza con la nueva impronta su contenido ético, también el respeto a los principios del ser humano obliga a aplicar a todo sucesor el filtro de la capacidad sucesoria.

Coincido entonces con el criterio de este autor, reafirmando que en el específico caso de la última causal de incapacidad, sería factible su aplicación en los supuestos de negativa de atención por parte del legitimario al causante. Téngase en cuenta que bien pudiera aquel pariente dependiente económicamente del causante, ser la persona que permanezca más próxima a éste y de quien pudiera necesitar asistencia, no de sustento pero sí de cuidados y atenciones que dignifiquen su existencia física y cuya negativa haría indiscutiblemente indigno al legitimario de toda protección sucesoria.

\section{II.2. Características} características:

El sistema legitimario que regula el Código Civil de 1987 tienen las siguientes

\footnotetext{
${ }^{44}$ El criterio de renunciabilidad legitimaria, ha sido también seguido por Pérez Gallardo (2004, 265).

45 Vid. por ejemplo, Vallet (I978, I8) y Rivera (I994, 4I8).
} 
I. Es de tipo asistencial. Se traslada su fundamento a la asistencia de quienes pueden ver comprometida su supervivencia tras el fallecimiento de un ascendiente, descendiente o cónyuge, reforzando de este modo el contenido ético del deber legitimario.

Con la implantación del régimen asistencial, se produce en Cuba una restricción subjetiva en la sucesión legitimaria por la incorporación de requisitos que reducen el número de beneficiarios. El artículo 493 del Código Civil cubano en su apartado primero regula que «Son herederos especialmente protegidos, siempre que no estén aptos para trabajar y dependan económicamente del causante, los siguientes:...», quedando establecidos los requisitos de asistencia por el enlace de una conjunción copulativa. Tal estado de cosas supone que no basta que sólo uno $u$ otro, a pesar de que pudieran perfectamente tipificarse de forma exclusiva, se ponga de manifiesto, sino que se requiere que la dependencia económica de los legitimarios respecto al causante se produzca por su incapacidad para trabajar ${ }^{4}$.

2. Es una legítima de arraigo romano (Pérez Gallardo, 2004, 260) y, por tanto, en atención a su aspecto funcional pertenece al sistema de reglamentación negativa o de freno, operando como una pars debita que el testador está obligado a atribuir a determinados sujetos.

3. La cuantía o extensión de la porción legitimaria la determina el ordenamiento jurídico en todos los casos y en ambas dimensiones: global e individual, estableciendo una cuantía alícuota e invariable para la primera, quien quiera que sean los legitimarios, y la regla de la equidad para la segunda ${ }^{47}$.

4. A tenor de la interpretación del artículo 494 del Código Civil puede ser satisfecha por cualquier título. Ello constituye un tributo legislativo a la preservación, aún en un sistema de legítimas, de la libertad de testar.

\footnotetext{
${ }^{46}$ Vid. Sentencia No. I89 de 3I de marzo de 2003 de la Sala de lo Civil y lo Administrativo del Tribunal Supremo Popular que estima como heredera especialmente protegida a la viuda del testador porque cumplía ambos requisitos además del conyugal; Sentencia No. 75 de 3I de marzo del 2009 de la Sala de lo Civil y lo Administrativo del Tribunal Supremo Popular, Segundo Considerando: «... la doctrina científica al estudiar la instituto de los herederos especialmente protegidos ... demanda además la dependencia económica del causante y la no aptitud para trabajar, -lo que le incorpora cierto carácter transitorio-, de tal suerte que esta especial protección no existe por el solo hecho del nacimiento ni por la formalización o reconocimiento judicial del matrimonio, o sea no es suficiente el vínculo parental o marital, es indispensable el cumplimiento de dos requisitos o requerimientos legales a saber...» y Sentencia No. 296 de 29 de abril del 2005 de la Sala de lo Civil y de lo Administrativo del Tribunal Supremo Popular, que en su segundo Considerando valora que «(...) al haberse fundado el fallo de la sentencia impugnada en el hecho de no haberse acreditado que en la recurrente concurriesen los requisitos para que le alcance la condición de heredera especialmente protegida que concede el artículo cuatrocientos noventa y tres inciso uno del Código Civil, al no demostrarse su dependencia económica con el testador, e incapacidad para trabajar, puesto que la misma en la actualidad recibe el veinticinco por ciento del salario que percibía como trabajadora, al aplicársele la Resolución número seis de mil novecientos noventa y seis, tras diagnosticársele la enfermedad que padece de artritis reumatoide, que por otra parte, no se afirma la incapacite para dedicarse a otras labores que estén fuera de las excluidas, según el resultado del peritaje médico realizado; con base en el amparo escogido era obligado a aceptar tales presupuestos de hechos ...».

47 Vid. artículos 492 y 493 apartado segundo del Código Civil cubano.

Artículo 492.I. La libertad de testar se limita a la mitad de la herencia cuando existen herederos especialmente protegidos.

2. El testador no puede imponer gravamen alguno a la porción de la herencia que corresponde a los herederos especialmente protegidos.

Artículo 493.I. Son herederos especialmente protegidos, siempre que no estén aptos para trabajar y dependan económicamente del causante, los siguientes:

a) Los hijos o sus descendientes en caso de haber premuerto aquéllos;

b) el cónyuge sobreviviente; $y$

c) los ascendientes.

2. Si concurren a la herencia dos o más herederos especialmente protegidos, heredan por partes iguales.
} 
5. Atendiendo a su contenido es una legítima pars bonorum, lo que constituye una derivación de la característica anterior.

6. Por su extensión o cuantía se presenta como una legítima larga, en tanto comprende la mitad del patrimonio del causante.

7. Opera como una limitación a la facultad dispositiva del causante que no se restringe a los actos mortis causa sino que confina igualmente las actuaciones gratuitas del causante por actos inter vivos ${ }^{4}$. No obstante tiene naturaleza mortis causa porque constituye un modo de adquirir la propiedad por causa de muerte.

8. Está articulado mediante normas de ius cogens que garantizan la rectoría del principio de intangibilidad de la legítima en los órdenes cuantitativo y cualitativo. Así los artículos del 492 al 495 del Código Civil constituyen una manifestación del método imperativo en el ordenamiento de este tipo en Cuba.

9. Es una legítima de concurrencia o colectiva porque tienen derecho a percibirla todos aquellos sujetos que el Código concibe como legitimarios sin prelación, excepto en el primer grupo que corresponde a los descendientes porque en él sí que impone el inciso a) del apartado primero del artículo 493 que a partir del segundo grado en este línea, concurran sólo en caso de premuerte de los del primero ${ }^{49}$. Esta característica como veremos luego incide en la determinación de los efectos de la total vulneración de la legítima.

Io. No tiene cabida alguna en la sucesión intestada ${ }^{50}$ según las previsiones normativas, por cuanto se concibe exclusivamente en la sucesión testamentaria ex artículo 492 y siguientes sin que las normas reguladoras de la ab intestato configuren su contenido, sus efectos, su nomenclatura ni atisbo alguno que viabilice en su terreno este tipo de sucesión. De este modo, incurre el legislador en una omisión de aciaga trascendencia por cuanto desnaturaliza el sistema asistencial con que concibe a la sucesión forzosa y su carácter concurrente o colectivo, razonamiento que queda claro si se atiende a que son distintos los llamados sucesorios ab intestatos y los legitimarios. Así tenemos no sólo que en la sucesión intestada los herederos especialmente protegidos en caso de ser descendientes, cónyuges o padres con especial protección adquirirán porciones iguales al resto de los sucesores legales que no ostenten tal condición, sino además que pudieran no recibir nada si se trata de ascendientes a partir del segundo grado en caso de que existan parientes más próximos por la aplicación de la exclusión de grados que informa a la sucesión sin testamento. A esto le han llamado Cobas Cobiella y Pérez Gallardo (I997, 70) una de las más connotadas antinomias del Código Civil cubano.

II. El cónyuge adquiere su porción legitimaria en propiedad igual que el resto de los legitimarios. Ello constituye un reflejo de uno de los principales cambios operados tras la entrada en vigor del Código Civil cubano consistente en la ostensible mejora sucesoria del cónyuge supérstite.

\footnotetext{
${ }^{48}$ Vid. artículos 378 a) y 530 del Código Civil cubano.

Artículo 378 . Es rescindible, por inoficiosa, la donación que:

a) Excede lo que puede darse o recibirse por testamento; $y$

Artículo 530.I. En el caso de sucesión testamentaria, de existir herederos especialmente protegidos, el valor de todo bien que los instituidos herederos hayan recibido del causante, por donación u otro título lucrativo, debe ser incluido en la masa hereditaria a los efectos de la partición.

2. En la sucesión intestada se trae a la masa hereditaria el exceso del valor de las donaciones declaradas inoficiosas.

3. La colación es exigible tanto al que hereda por derecho propio como por derecho de representación.

49 Vid. artículo 493.

50 Vid. Sentencia No. I80 de I5 de marzo de 2005, Segundo Considerando, de la Sala de lo Civil y lo Administrativo del Tribunal Supremo Popular y Caravia Díaz (20I0, 98).
} 


\section{II.3. Desaciertos fundamentales}

II.3.I. En cuanto a la concepción general del régimen legitimario

Del estudio de las características anteriores, salta la primera de las deficiencias del sistema legitimario cubano, relativa a su circunscripción a la sucesión testada. En otro orden pueden enumerarse las siguientes:

I. Indebida concepción de la colación hereditaria por cuanto no se relacionan los bienes colacionables ni el modo de hacerlo, no se regula la facultad de dispensar, aunque esta laguna no implica su prohibición y como colofón inexplicablemente se prevé en la sucesión intestada ${ }^{51}$.

2. Omisión de la facultad de desheredar.

3. Prelación en la condición de heredero especialmente protegido para el primer grupo que corresponde a la línea recta descendiente.

\section{II.3.2. En cuanto al régimen de protección en particular}

I. Indebida equiparación de los efectos de la preterición en los supuestos de violación de la legítima global e individual.

2. Efecto nulificante de la institución de herederos ante todos los supuestos en los que se estime la preterición. Esto ha contribuido, junto al enunciado del artículo 509 inciso a), a que se asuma la apertura de la sucesión intestada como consecuencia directa ${ }^{52}$ y en esta se adjudique el heredero especialmente protegido sólo la cuota ab intestato (Pérez Gallardo 2004,280 ), por esta razón puede que no alcance a adjudicarse lo que por su condición le ha de corresponder, teniendo en cuenta la expectativa de concurrencia a la legítima cubana que difiere de la que opera en la intestada y su composición.

3. Omisión normativa en cuanto a las acciones para hacer efectiva la reducción de legados. Se establece la validez los legados en cuanto no excedan la parte de libre disposición, dejando un espacio al mantenimiento de la voluntad del causante que aunque en el orden teórico resulta positivo, dada la falta de regulación del modo de hacer efectiva la reducción unida a la actual interpretación de los efectos de la preterición, no logra desplegar con adecuado alcance la tuición para la que fue prevista. Además, la asimilación de la reducción de los legados violatorios de la legítima, de acuerdo a la interpretación vigente resulta muy compleja pues si la nulidad de la institución de herederos deriva a la apertura de la sucesión intestada, no es consecuente para la propia norma, ni para la doctrina

\footnotetext{
${ }^{5}$ Vid. artículo 530 apartado segundo del Código Civil cubano.

${ }^{2}$ Vid. en este sentido como en la Sentencia $N^{\circ}$ i2O de 28 de febrero del 2005 de la Sala de lo Civil y de lo Administrativo del Tribunal Supremo cubano, en su Único Considerando, refleja la Sala que por derivación de la precedente nulidad de la cláusula de institución de heredero testamentaria se produjo la apertura de la sucesión intestada, sólo como elemento de hecho y no de Derecho incorporado a la resolución judicial: «(...) lo cierto es que por sentencia firme se dispuso la nulidad del acto jurídico consistente en Testamento Notarial contenido en la Escritura número (...) otorgada (...) por el hecho de haberse infringido lo concerniente a la designación del heredero especialmente protegido, en este caso un hijo menor de edad, por lo que intrascendente resulta que con posterioridad a la firmeza de dicha sentencia dicho menor hubiere abandonado el país definitivamente pues, para entonces ya había surtido todos los efectos legales en cuanto a la nulidad del mencionado instrumento, abriéndose así la sucesión intestada como en efecto fue verificado, alcanzando por tanto tal nulidad a los actos realizados en virtud del instrumento declarado nulo, en este caso, el acto jurídico de Aceptación y Adjudicación de Herencia contenido en la correspondiente escritura, respecto al cual se interesó su nulidad en el presente proceso (...)».
} 
jurídica, que la reducción de los legados que excedan la parte de libre disposición se efectúe, si no es para los casos en que de toda la herencia se haya dispuesto a título particular. libre disposición.

4. Omisión normativa en cuanto al destino de los legados que exceden la parte de

5. Indebida alusión al derecho de representación, regulado en el artículo 495.2, como vía por la que acceden a la legítima los descendientes de los herederos especialmente protegidos que han premuerto; siendo ésta una forma de suceder exclusiva de la sucesión intestada, y en este caso se la ubica participando en la regulación de la legítima. Establece el precepto indicado que la cláusula de institución de herederos mantiene su validez cuando el preterido premuere al testador sin haber dejado descendencia con especial protección. Se reafirman dos elementos de suma relevancia en este precepto. A pesar de su desafortunada formulación: se valora adecuadamente la importancia de la institución de herederos, haciéndola sobrevivir al supuesto de hecho que se enuncia y acto seguido, se reconoce la condición personalísima con que debe acudirse a la sucesión legitimaria. Sin embargo, empañando los aciertos anteriores, indebidamente el mismo precepto en su párrafo segundo, permite el acceso a los descendientes de todo legitimario preterido premuerto que reúnan las condiciones de especial protección, en franca colisión con la prelación que contiene el artículo 493 del mismo cuerpo legal en el que sólo se conciben con dicha condición a los descendientes de los hijos.

6. Omisión normativa de la protección de herederos especialmente protegidos cuasi póstumos, o sea, los que nacen en el período que media entre el otorgamiento del testamento y la muerte.

7. Omisión normativa de los efectos definitivos de la preterición o de la forma en la que se hace efectiva la atribución de legítima al preterido.

Con tal estado de cosas puede sostenerse la existencia de una verdadera crisis en el sistema de protección legitimaria que establece el Código Civil cubano, que va requiriendo la acuciosidad de los planteamientos teóricos en torno a esta forma de sucesión como premisa de su superación.

\section{Bibliografía}

ALBALADEJO, M. (2008): Curso de derecho civil, Edisofer.

ALCALÁ NAVARRO, A. (2009): Código civil: comentarios y jurisprudencia, Salas Carceller, A. (coord.), Madrid: Sepin, p. 23I2-235I.

ALGUER, J. (I93I): «Ensayos varios sobre temas fundamentales del Derecho Civil», Revista Jurídica de Cataluña, XXXVII, I931, p. 36-152.

BARRIO GALLARDO, A. (2007): «Atemperar la rigidez de la legítima», Aranzadi civil: revista doctrinal 3, p. 27II2738.

BARRIO GALLARDO, A. (20II): La evolución de la libertad de testar en el «Common Law» inglés, Navarra: Aranzadi.

BUSTO LAGO, J. M. (2009): «Artículos 806 al 822», en Bercovitz Rodriguez-Cano, R. (dir.), Comentarios al Código Civil, Navarra: Thomson-Reuters Aranzadi, p. 963-994.

CÁMARA LAPUENTE, S. (2000): La exclusión testamentaria de los herederos legales, Madrid: Civitas.

CÁMARA LAPUENTE, S. (2003): «Derecho Europeo de Sucesiones: un apunte», en Cámara Lapuente, S. (coord.), Derecho privado europeo, Madrid: Colex, p. II85-I233.

CARAVIA DÍAZ, E. (20IO): «Efectos de la Preterición de herederos en el ordenamiento civil cubano: ¿Reforma necesaria o Pretensiones vanidosas?», Trabajo de Diploma, Tutores: Leonardo B. Pérez Gallardo y Teresa Delgado Vergara. Universidad de la Habana, Facultad de Derecho, (versión digital). 
CONTRERAS, P. de P. (I987): «Preterición, Derecho intertemporal y Constitución española», Anuario de Derecho Civil tomo I XL fasc. II, p. 70I-7II.

DE LA CÁMARA ALVAREZ, M. (I999): Compendio de derecho sucesorio, Madrid: La Ley.

DE LA CÁMARA ALVAREZ, M. (20II): Compendio de derecho sucesorio, Madrid: La Ley.

DELGADO ECHEVERRÍA, J. (20II): «El fundamento constitucional de la facultad de disponer para después de la muerte», La Ley 7675, I8 de julio, p. 7-Io.

DÍEZ-PICAZO L. y GULLÓN, A. (I998): Instituciones de derecho civil, Madrid: Tecnos.

DOMíNGUEZ LUELMO, A. (20I0), «Artículos 806 al 8Io», en Domínguez Luelmo, A. (dir.), Comentarios al Código Civil, Valladolid: Lex Nova, p. 923 a 926.

DOMíNGUEZ LUELMO, A. (2010): «Artículos 8I5 al 822», en Domínguez Luelmo, A. (dir.), Comentarios al Código Civil, Valladolid, Lex Nova, p. 933 a 942.

ESPEJO LERDO DE TEJADA, M. (I996): La legítima en la sucesión intestada en el Código Civil, Madrid: Marcial Pons.

GARCIA MORENO, J. M. (I995): «La preterición de herederos forzosos en el derecho común tras la reforma de I98I», Actualidad Civil 44, p. 893-906.

GARCÍA MORENO, J. M. (2008): «La preterición de herederos forzosos», Manuales de formación continuada 47 p. 603-690.

GONZÁlEZ COLLADO, S. (I946): «El legitimario no es sucesor», Anales de la Academia Matritense del Notariado tomo III, pp. 533-54I.

LACRUZ BERDEJO, J. L. y SANCHO REBULLIDA, F. de A. (I973): Elementos de Derecho Civil, Barcelona: José María Bosch.

LACRUZ BERDEJO, J. L. (I993): Elementos de Derecho Civil, Barcelona: José María Bosch.

LLEDÓ YAGÜE, F. (2008): Compendio de Derecho civil, Madrid: Dykinson.

LLEDÓ YAGÜE, F. (200I): «La tutela de la legítima formal», en Homenaje a Don Antonio Hernández Gil, Madrid: Centro de Estudios Ramón Areces, p.2524-2560.

LLEDÓ YAGÜE, F. (2002): Sistema de derecho civil: derecho de sucesiones, Madrid: Dykinson.

LÓPEZ FRÍAS, M. J. (200I): «Comentario a la S.T.S. de 23 de enero de 200I: problemas interpretativos en relación a la preterición», Boletín de Información del Colegio Notarial de Granada, p. I775-I785.

MARTÍN PEREZ, J. A. (2000): «Sección Quinta de las Legítimas», en Pasquau Liaño, M. (dir.), Jurisprudencia civil comentada: código civil, Granada: Comares, p. I475-I533.

MIQUEL GONZÁLEZ, J. M. (2002): «Preterición no intencional. Momento decisivo para juzgar la no intencionalidad. Comentario a la STS de 23 enero 200I», Revista de derecho patrimonial 9, p. 53I-538.

MIQUEL GONZÁLEZ, J. M. (2003): «Acción de reclamación de filiación extramatrimonial y preterición intencional: comentario a la STS de 9 julio 2002 (RJ 2002, 8237)», Revista de derecho patrimonial Io, p. 433-442. (A), tomo 49, p. 493-560.

MIQUEL GONZÁLEZ, J. M. (2003): «La preterición», en Estudios jurídicos en homenaje al profesor Luis DíezPicazo, Madrid: Civitas, p. 5339-5390. (B), Nº 9, p. 53I-537.

MIQUEL GONZÁLEZ, J. M. (2009): «Legítima material y legítima formal», Anales de la Academia Matritense del Notariado.

MORENO MOZO, F. (2009): «El doble concepto de sujeto preterible contenido en el art. 8I4 del Código Civil», Actualidad civil I8, p. I-I9.

O'CALLAGHAN, X. (2006-2007): Compendio de derecho civil, Madrid: Edersa.

O'CALLAGHAN, X. (2008): Código civil: comentado $y$ con jurisprudencia, Madrid: La Ley.

ORTEGA PARDO, G. (I950): «Heredero testamentario y heredero forzoso», Anuario de derecho civil Vol. 3, 2, p. 32I-36I.

PEÑA BERNALDO DE QUIRÓS, M. (I985): «La naturaleza de la legítima», Anuario de Derecho Civil XXXVIII-IV octubre-diciembre, p. 849-907.

PEREÑA VICENTE, M. (2003): «La reforma del Derecho sucesorio francés llevada a cabo por la Ley de 3 de diciembre de 200I», Revista crítica de derecho inmobiliario 679 Año 79, p. 2855-2878.

PÉREZ GALLARDO, L. B. y COBAS COBIELLA, M. E. (I997): «A una década de la promulgación el Código Civil cubano: reflexiones sobre algunos aciertos y desaciertos de su Libro Cuarto», Temas de Derecho Sucesorio Cubano, La Habana: Félix Varela, p. 36-9o. (A) 
PÉREZ GALLARDO, L. B. y COBAS COBIELLA, M. E. (I997): «Los herederos especialmente protegidos, la nueva visión de los legitimarios en el Código Civil cubano: algunas interrogantes al respecto», Temas de Derecho Sucesorio Cubano, La Habana: Félix Varela, p. I-50. (B)

PÉREZ GALLARDO, L. B. (2004): «Los herederos especialmente protegidos. La legítima. Defensa de su intangibilidad cualitativa y cuantitativa», Derecho de Sucesiones, La Habana: Félix Varela, p. 200-3Io.

PÉREZ GALLARDO, L. B. (2009): «El Derecho de Sucesiones en cifras, Recapitulación y Pronósticos», Anales de la Real Academia de Jurisprudencia y Legislación 39, p. 70I-765.

QUINCE FANJUL, J. A. (2008): «Preterición: interpretación del art. 8I4.3 Cc», Revista jurídica de Asturias 32, p. II5-I27.

REAL PÉREZ, A. (I988): Intangibilidad cualitativa de la legítima, Madrid: Civitas.

RENTERÍA AROCENA, A. (2OII): «La libertad de testar en Derecho Comparado», Revista crítica de derecho inmobiliario 726 año 87, p. 2095 -2128.

RIVAS MARTÍNEZ, J. J. (2009): Derecho de sucesiones común y foral, Madrid: Dykinson.

RIVERA FERNÁNDEZ, M. (I994): La preterición en el Derecho común español, Valencia: Tirant lo Blanch.

ROCA SASTRE, R. M. y PUIG BRUTAU, J. (2009): Estudios de derecho privado, Aranzadi-Thomson Reuters.

RÖTHEL, A. (2008): El derecho de sucesiones y la legítima en el derecho alemán, traducción de Antoni Vaquer Aloy, Barcelona: Bosch.

TORRES GARCÍA, T. F. (2009): «La legítima en el Código Civil», en Álvarez González, S., García Rubio M. P., Requejo Isidro, M. (coord.), Estudios de derecho de familia $y$ de sucesiones: (dimensiones interna $e$ internacional), España, p. 297-322.

TORRES GARCÍA, T. F. y DOMÍNGUEZ LUELMO, A. (20II): «La legítima en el Código Civil I», en GeteAlonso y Calera, M. del C. (dir.), Tratado de derecho de sucesiones: código civil y normativa civil autonómica: Aragón, Baleares, Cataluña, Galicia, Navarra, País Vasco, Navarra: Civitas, p. I84I-I897.

TORRES GARCÍA, T. F. y DOMÍNGUEZ LUELMO, A. (20II): «La legítima en el Código Civil I», en María del Carmen Gete-Alonso y Calera (dir.), Tratado de derecho de sucesiones: código civil y normativa civil autonómica: Aragón, Baleares, Cataluña, Galicia, Navarra, País Vasco, Navarra: Civitas, p. I899-I958.

TORRES GARCÍA, T. F. (2006): «Legítima, legitimarios y libertad de testar (síntesis de un sistema)», Derecho de sucesiones: presente y futuro, XI Jornadas de la Asociación de Profesores de Derecho Civil, Santander, 9 a II de febrero de 2006, Servicio de Publicaciones, Murcia, p. I73-230.

VALLADARES RASCÓN, E. (2004): «Por una reforma del sistema sucesorio del Código Civil», en González Porras, J. M. (coord.), Libro homenaje al profesor Manuel Albaladejo García, Murcia: Colegio de Registradores de la Propiedad y Mercantiles de España, p. 4893-4902.

VALLET DE GOYTISOLO, J. B. (I966): «Significado jurídico-social de las legítimas y de la libertad de testar», Anuario de derecho civil I vol. I9, p. 3-44.

VALLET DE GOYTISOLO, J. B. (I967): «El deber formal de instituir herederos a legitimarios y el actual régimen de preterición en los derechos civiles españoles», Anuario de derecho civil I vol. 20, p. 3-II6.

VALLET DE GOYTISOLO, J. B. (I972): «Atribución, concreción del contenido y extinción de las legítimas», Anuario de derecho civil I vol. 25, p. 3-I5I.

VALLET DE GOYTISOLO, J. B. (I973): «Los complementos de la legítima», Anuario de derecho civil I vol. 26, p. 3-46.

VALLET DE GOYTISOLO, J. B. (I974): «Las Legítimas según Claude Chiffle», Anuario de Derecho Civil tomo XXVII Fascículo III, p. 679-693.

VALLET DE GOYTISOLO, J. B. (I978): Comentarios al Código Civil $y$ compilaciones forales dirigidos por Manuel Albaladejo y Silvia Díaz Alabart, Madrid: EDERSA, p. I-225.

VALLET DE GOYTISOLO, J. B. (I982): Panorama del derecho de sucesiones, Madrid: Civitas.

VALLET DE GOYTISOLO, J. B. (I986): «Aclaraciones acerca de la naturaleza de la legítima», Anuario de derecho civil 3 vol. 39, p. 833-849. (A)

VALLET DE GOYTISOLO, J. B. (1986): «Observaciones en torno a la naturaleza de la legítima», Anuario de Derecho Civil I vol. 39, p. 3-68. (B)

VALLET DE GOYTISOLO, J. B. (I99I): «Sección Quinta de las Legítimas», en Paz-Ares Rodríguez, C. y Díez Picazo, L. (dir.), Comentario del Código Civil, Madrid: Centro de Publicaciones, Ministerio de Justicia, p. I967-2032.

VAQUER ALOY, A. (20I0): «La convergencia espontánea del Derecho de Sucesiones en Europa», Obligaciones $Y$ sucesiones en el Derecho comparado, Perú: ARA Editores, E.I.R.L., p. I83-213. 
VILLARRUBIA MARTOS, J. (2OII): «El decreto de Declaración de herederos a la luz de la Ley I3 de 2009», Diario La Ley 7687, 5 de septiembre de 20II, p. I - I6.

ZACCARIA, A. (2008): Perfiles del derecho italiano de sucesiones, Barcelona: Bosch.

\section{Fuentes legales}

Código Civil de la República Argentina, Ley 340 de 25 de septiembre de 1869.

Código Civil de la República de Colombia, Ley 57 de I887de 26 de mayo de I873, edición a cargo de Luis César Pereira Monsalve, Medellín, marzo, I994.

Código Civil de la República de Costa Rica, Ley No. 63 de 28 de septiembre de I887, vigente desde el iro de enero de I888.

Ley de Procedimiento Civil Administrativo y Laboral, Ley No. 7 de 1977 de I9 de agosto, en Gaceta Oficial Ordinaria, No. 34, de 20 de agosto de I977. Cuba.

Ley De las Notarías Estatales, Ley No. 50 de I984 de 28 de diciembre MINJUS, La Habana, I986. Cuba.

Ley No. 59/1987 de I6 de julio anotado y concordado por Leonardo B. Pérez Gallardo, Ediciones ONBC, La Habana, 2007.

Código Civil de la República de Ecuador, Codificación No. ○o०. RO/ Suplemento Io4 de 20 de Noviembre de I970, consultado en www.legislacionandina.com, el 6 de septiembre de $201 \mathrm{I}$.

Ley de Enjuiciamiento Civil de I88I (modificados por la Ley No. Io de 30 de abril de I992). España.

Código Civil del Reino de España de 6 de octubre de I888, Gaceta de 25 de julio de I889.

Ley No. 6 de Iro de julio de I985, Ley Orgánica del Poder Judicial. España.

Ley No. I de 7 de enero de 2000 de Enjuiciamiento Civil. España.

Ley No. I3 de 23 de noviembre de 2009 sobre reforma de la legislación procesal para la implantación de la nueva Oficina Judicial. España.

Código Civil de la República de Honduras, de I4 de septiembre de I989, Congreso Nacional de Honduras.

Código Civil Federal de México de I928, última reforma publicada en DOF el 3I de diciembre de 2004, vigente a partir del $\mathrm{I}^{\mathrm{o}}$ de enero de 2005 .

Código Civil de la República Oriental del Uruguay, de I de enero de I868, modificado en I995.

Código Civil de Venezuela de 26 de julio de I982,

Fuero Nuevo de Navarra, Ley I de Iro de marzo de i973.

Ley de Sucesiones por Causa de muerte de Aragón, Ley I de 24 de febrero de I999.

Código Civil de Cataluña, Ley io de io de julio de 2008, consultado en www.westlaw.es, el I2 de septiembre de 2011.

Código del Derecho Foral de Aragón publicado en el Boletín Oficial de Aragón de 29 de marzo de 20II.

Código Civil de Bolivia, Decreto-Ley I2760 de 6 de agosto de I975, modificado por la Ley or8 de I6 de junio de 2010.

Decreto- Ley No.II7 de I989, Del Registro de Actos de Última Voluntad y de Declaratoria de Herederos. Cuba.

Decreto- Ley 24I de 24 de enero de 2006 sobre modificaciones a la Ley de Procedimiento Civil, Administrativo, Laboral y Económico. Cuba.

Código Civil de la República de Chile, Decreto No. I937 de I976 del Ministerio de Justicia, de I4 de diciembre de I855, edición oficial al 3i de agosto de I976, Editorial Jurídica de Chile.

Código Civil italiano Decreto Real No. 262 de I6 de marzo de I942, última actualización marzo de 2000.

Código Civil de Perú, Decreto Legislativo No. 925 promulgado el 24 de julio de I984 y entrada en vigor el I4 de noviembre de 1984 .

Resolución No. 7 de I990 del Ministerio de Justicia: Reglamento del Registro de Actos de Última Voluntad y de Declaratoria de Herederos.

Resolución No. 70 de I992 del Ministerio de Justicia: Reglamento de la Ley de Notarías Estatales. 


\section{Resoluciones de la Dirección General de los Registros y el Notariado}

Resolución de 4 de mayo de I999. RJ\I999\325I

Resolución de I3 de septiembre de 200I. RJ\2002\24IO

Resolución No. I de I3 de octubre de 2005. RJ $2005 \backslash 7452$

Resolución de I de marzo de 2006. RJ\2006\3919

\section{Sentencias de la Sala de lo Civil y lo Administrativo del Tribunal Supremo Popular} (Cuba)

Sentencia No. 934 de 29 de noviembre de 1996.

Sentencia No. I89 de 3I de marzo de 2003.

Sentencia No. I20 de 28 de febrero del 2005.

Sentencia No. I80 de 15 de marzo de 2005.

Sentencia No. 296 de 29 de abril del 2005.

Sentencia No. 75 de 3I de marzo del 2009

\section{Sentencias de la Sala de lo Civil del Tribunal Supremo (España)}

Sentencia de 20 de febrero de I98I. RJ \I98I \534

Sentencia de I3 de julio de I985. RJ\I985\4052

Sentencia No. 5I de 30 de enero de I99I. RJ\I995\388

Sentencia No. 3I0 de 6 de abril de I998. RJ\I998\I9I3

Sentencia No. 725 de 9 de julio de 2002. RJ \2002\8237

Sentencia No. 765 de I3 de octubre de 2005. RJ $2005 \backslash 7233$

Sentencia No. 669 de 22 de junio 2006. RJ \2006\3082 